\title{
Advancing the Science of Environmental Flow Management for Protection of Temporarily Closed Estuaries and Coastal Lagoons
}

\author{
Eric D. Stein ${ }^{1, *(\mathbb{C}}$, Eleanor M. Gee ${ }^{2}$, Janine B. Adams $\left.{ }^{3}{ }^{(}\right)$, Katie Irving ${ }^{1}\left(\mathbb{C}\right.$ and Lara Van Niekerk ${ }^{3,4}(\mathbb{D}$ \\ 1 Southern California Coastal Water Research Project (SCCWRP), Costa Mesa, CA 92626-1437, USA; \\ katiei@sccwrp.org \\ 2 National Institute of Water \& Atmospheric Research Ltd. (NIWA), Hamilton 3216, New Zealand; \\ Eleanor.Gee@niwa.co.nz \\ 3 Department of Botany, Institute for Coastal \& Marine Research, Nelson Mandela University, \\ Port Elizabeth 6031, South Africa; janine.adams@mandela.ac.za (J.B.A.); lvnieker@csir.co.za (L.V.N.) \\ 4 Council for Scientific and Industrial Research (CSIR), Stellenbosch 7600, South Africa \\ * Correspondence: erics@sccwrp.org; Tel.: +1-714-755-3233
}

Citation: Stein, E.D.; Gee, E.M.; Adams, J.B.; Irving, K.; Van Niekerk, L. Advancing the Science of Environmental Flow Management for Protection of Temporarily Closed Estuaries and Coastal Lagoons. Water 2021, 13, 595. https://doi.org/ 10.3390/w13050595

Academic Editor: David Dunkerley

Received: 31 December 2020

Accepted: 19 February 2021

Published: 25 February 2021

Publisher's Note: MDPI stays neutra with regard to jurisdictional claims in published maps and institutional affiliations.

Copyright: (c) 2021 by the authors. Licensee MDPI, Basel, Switzerland. This article is an open access article distributed under the terms and conditions of the Creative Commons Attribution (CC BY) license (https:/ / creativecommons.org/licenses/by/ $4.0 /)$.

\begin{abstract}
The science needed to inform management of environmental flows to temporarily closed estuaries and coastal lagoons is decades behind the state of knowledge for rivers and large embayments. These globally ubiquitous small systems, which are often seasonally closed to the ocean's influence, are under particular threat associated with hydrologic alteration because of changes in atershed land use, water use practices, and climate change. Managing environmental flows in these systems is complicated by their tight coupling with watershed processes, variable states because of intermittently closing mouths, and reliance on regional scale sediment transport and littoral processes. Here we synthesize our current understanding of ecohydrology in temporarily closed estuaries (TCEs) and coastal lagoons and propose a prioritized research agenda aimed at advancing understanding of ecological responses to altered flow regimes in TCEs. Key research needs include agreeing on a consistent typology, improving models that couple watershed and ocean forcing at appropriate spatial and temporal scales, quantifying stress-response relationships associated with hydrologic alteration, improving tools to establish desired conditions that account for climate change and consider cultural/indigenous objectives, improving tools to measure ecosystem function and social/cultural values, and developing monitoring and adaptive management programs that can inform environmental flow management in consideration of other stressors and across different habitat types. Coordinated global efforts to address the identified research gaps can help guide management actions aimed at reducing or mitigating potential impacts of hydrologic alteration and climate change through informed management of freshwater inflows.
\end{abstract}

Keywords: environmental flows; ecohydrology; estuary function; water resources management

\section{Introduction}

The risk to estuarine habitats and the underlying processes that support them from alteration of freshwater inflows is growing as a result of increasing competition for freshwater resources and power generation, and because of hydrological changes associated with climate change and land use practices. The growing risk, accompanied by the complex and contentious nature of water resources management decisions, increases the urgency for developing scientifically robust and defensible assessments of the environmental flow needs of estuaries.

The 2018 update to the Brisbane Declaration on Environmental Flows revised the definition of environmental flows to explicitly recognize "the critical linkages between freshwater and estuarine ecosystems and the human livelihoods and well-being that depend on these ecosystems" and include estuaries as vital component of environmental flow management [1]. In summarizing a special issue devoted to environmental flows, 
Arthington et al. [2] recommended the inclusion of additional waterbody types, such as estuaries and other coastal ecosystems as a key element in advancing the management of environmental flows.

Environmental flows studies in estuarine environments pose unique challenges because of the spatial gradients and temporal variability associated with the combined influence of fluvial and oceanic inputs [3]. Riverine (fluvial) inflows influence the physical environment of the ecosystem in terms of water chemistry, stratification and mixing, water level and habitat structure/diversity, temperature and exchange with the marine environment. Riverine inflows also influence geomorphological features such as sand bars, channel structure and the opening and closing of the estuary's entrance [4,5]. Marine (oceanic) inflows similarly influence water chemistry, stratification and mixing, and provide the predominant control of water level, temperature, residence time and flushing by controlling the morphology and opening of the estuary mouth associated with littoral sand deposition and wave action on the mouth berm [6]. Hydrologic change can alter the prevailing physical environment in the estuary with implications for flora and fauna, such as cues for migration, life history processes and recruitment $[4,7]$.

As some of the most impacted environments on earth, estuaries can benefit greatly from the application of environmental flow science. However, the development of methods to address the environmental flow needs of estuaries has lagged behind the development of methods for rivers [8]. Efforts that have occurred have focused on large estuaries such as Bay of Bengal, Puget Sound, Galveston Bay, California Bay-Delta [9-12]. Less effort has focused on smaller temporarily closed estuaries (TCEs) and coastal lagoons. These resources comprise the vast majority of coastal estuaries and lagoons worldwide and provide many ecosystem functions $[7,13]$. Moreover, these systems, because of their relatively small size, are under particular threat because of the combination of changing water use practices in coastal watersheds, climate change, and the effect of other stressors, such as pollutant or nutrient input.

Recently, several authors have proposed frameworks for assessing ecological flows in estuaries [14,15]. These frameworks provide an important starting point for advancing the field of estuarine ecohydrology, but at the same time begin to highlight key knowledge gaps that need to be addressed in order to fully advance development of environmental flow programs for TCEs. Temporarily closed estuaries are referred to by many different names and occur worldwide but are prominent in Mediterranean climates such as those found in southwestern North America, northern South America, western and southern Africa, Australia and New Zealand where they comprise a large proportion of the estuarine habitat $[6,16,17]$. Developing a consensus research framework for addressing key knowledge gaps important for informing management decisions will foster collaboration and information sharing that can advance protection and restoration of these systems globally.

Building on discussions from an international special session at the 2019 Coastal and Estuarine Research Federation Annual meeting, we outline research priorities for advancing the science and practice of environmental flow management for estuaries. Our goals are to summarize the status of the science and articulate knowledge gaps that if filled would facilitate informed management decisions.

\section{A Framework for Establishing Research Priorities}

Flows necessary to support healthy estuaries can be based on many assessment and management endpoints including intact biological communities, natural physical processes, or cultural/societal uses and values. Here, we expand on a framework developed by Van Niekerk et al. [18] for establishing ecological flow requirements in estuaries to consider both ecological and social/cultural needs. The framework is used to highlight key knowledge gaps and research needs necessary for advancing environmental flow programs for TCEs. The Van Niekerk et al. [18] framework provides seven basic steps to establish flow requirements for estuaries in South Africa:

1. Simulation and interrogation of hydrological data (natural, present and future); 
2. Zonation of the estuary into a functionally homogenous area;

3. Identification of characteristic physical states;

4. Evaluation of temporal (annual/seasonal) distribution in physical states;

5. Prediction of biotic responses to flow changes;

6. Definition of present and setting desired condition;

7. Allocation of environmental flow requirements

Establishing environmental flow requirements for TCEs globally, requires expansion of the Van Niekerk et al. [18] framework to provide additional specificity on ocean vs. watershed driven hydrology and on the relationships between estuary state, bio-physical process, and ecological function (Figure 1). Temporary closed estuary process and function is tightly coupled to both ocean and watershed forcing of flow and sediment; development of ecological flow requirements calls for an understanding of the relationship between these two forces and how the balance of forcing may be affected by changes in freshwater inflows. Similarly, additional research is needed on the relationship between changes in freshwater inputs and ecological functions and how those changes may influence desired conditions and decisions regarding environmental flow requirements. Finally, development of environmental flow requirements requires consideration of monitoring and adaptive management strategies that can be used to gauge how successful allocated environmental flows are at providing and sustaining functions, and to trigger adaptive management actions when necessary. The revised framework shown in Figure 1 provides a conceptual model to guide future research priorities necessary to inform development of environmental flow requirements. In this paper, we elaborate on this conceptual model by suggesting refinements of existing typologies to better capture short and long term variability of inflows to TCEs, discussing key watershed and marine drivers that affect hydrologic change, evaluating stressors that influence hydrologic alteration and associated TCE functions, relating potential hydrologic alteration to expected management outcomes from both ecological and social perspectives, and proposing an enhanced monitoring and adaptive management framework. For each section, we summarize knowledge gaps and research needs. We conclude by rating research needs based on four factors and proposing the highest priority research needs that would advance management of environmental flows in TCEs.

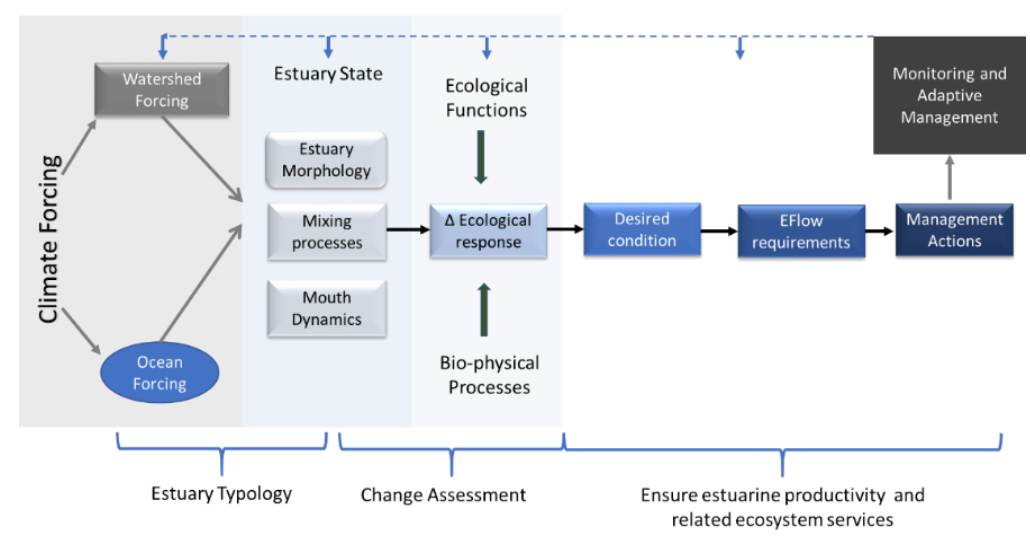

Figure 1. Framework for establishing ecological flow requirements. Key research gaps exist for understanding how climate forcing and estuary typology affect ecological functions and inform desired conditions, monitoring and adaptive management.

\section{Estuarine Typology and Classification}

In general terms, an estuary is where a river meets the ocean and is influenced by both tidal range and freshwater inflow. However, under such a broad description, estuary types vary, the classification of which has been a matter of debate over time [19]. This paper focuses on smaller TCEs, characterized by low a tidal range $(<2 \mathrm{~m},[20-22])$ and typically having constricted mouths that exhibit limited flushing and long residence times 
of water [23,24], causing them to be highly sensitive to changes in freshwater inflow. These systems are open to the ocean, sometimes nearly permanently, often temporarily with the duration and frequency of mouth closure a vital dynamic of estuary function. Temporarily closed estuaries are dominated by freshwater inflow (but also influenced by wave action and tides), and because of seasonal and/or low precipitation can form sand bars (or berms) that restrict tidal influence and create lagoons and lakes. In arid portions of the world, these systems may become hypersaline and provide unique sets of ecological functions.

The relationship between hydrologic forcing and ecological function varies based on the physical structure, size, coastal orientation, land-sea connection and state of an estuary. The degree to which hydrologic changes have the potential to affect zonation and mixing processes (and in turn estuary functions) will vary based on estuary type. Step 3 of the Van Niekerk et al. [18] framework involves identifying physical states of the estuary based on the occurrence and distribution of functionally homogenous zones and typology. These states influence hydrodynamics (e.g., floodplain inundation, connectivity, residence time), sediment deposition patterns, and water chemistry (e.g., salinity, dissolved oxygen), which can then be used to inform relationships between freshwater inflow patterns and desired biotic response. Typologies should account for general estuary structure, internal zonation patterns and status over multiple temporal scales (based on mouth closure status, climate, recent disturbance, etc.). Consideration of ecological response to magnitude, timing, and duration of inflows is an important first step in establishing desired environmental flow requirements for estuaries. The typology should be robust enough to accommodate the characteristics of individual systems. Ideally, such a typology should also relate to the International Union for Conservation of Nature's (IUCN) Global Ecosystem Typology (GET) for the Freshwater-Marine Realm (Level 1) and Transitional Waters Biome (Level 2), which is promoted for the IUCN red listing of ecosystems, reporting of Sustainable Development Goals 6 (SDGs), and Ecosystems Accounting processes [25]. However, this high-level typology only recognizes three types of estuary functional groups-deep-water coastal inlets, permanently open riverine estuaries and bays, and Intermittently closed coastal lagoons. Important types such as estuarine lakes/intermittently closed and open lakes and lagoon (ICOLLS), polar estuaries and hypersaline types are omitted from this classification, potentially making it impossible to report/disaggregate deteriorating conditions related to hydrologic change for a complete set of estuary types at a global level.

Estuary classification systems vary based on their intended applications. Classifications intended to support decisions about resilience to climate change may prioritize the role of catchment geology and climatic setting in controlling estuary structure and function [16]. Classifications intended to help evaluate susceptibility to pollutant effects may focus on estuary morphology and include factors that influence residence time, temperature, and salinity [26]. Whereas classifications aimed at assessing conservation significance often includes measures of catchment properties, hydrodynamics and estuary morphology $[27,28]$. A few systems aimed at inventory, mapping and general planning attempt to integrate water column, geology, substrate and biotic components into an overall classification system (e.g., the U.S. Interagency effort Coastal and Marine Ecological Classification System (CMECS)).

To be useful in guiding environmental flow requirements for TCEs, a classification system should emphasize the role of physical and hydrological factors that control morphology and ecological response in small to medium sized systems. Such systems tend to be heavily influenced by watershed characteristics and process, such as rainfall, catchment geology and associated sediment supply [29]. Most existing classifications are based on some combination of watershed characteristics and runoff patterns, tide or wave energy, and estuary basin size and morphology. Roy et al. [30] classified Australian estuaries into four basic types; open embayments, drowned valley (tide dominated estuaries), barrier (wave dominated estuaries) and intermittent estuaries, based on their geologic formation processes, depositional environment and maturity. Ryan et al. [13] expanded the Australian estuary classification to seven classes based largely on the balance of forcing 
from waves, tides, and rivers. Classifications that focus on temporarily closed estuaries include aspects of mouth position, state, and composition [6,31]. South Africa recently reclassified its estuaries to reflect greater sensitivity to pressures; the new classification reflects estuary size, mouth state, geomorphology/shape, tidal amplitude, salinity regime, typical mixing processes, sediment stability, and relative catchment flows (mean annual runoff) [32]. Similar to McSweeney et al. [6], the updated classification strives to increase resolution for the large number temporarily closed estuaries occurring along this diverse South African coastline.

Very few (if any) classification systems couple overall estuary structure with state relative to patterns in season or interannual forcing. Changes in littoral sand input, fluvial forcing, and sediment supply can affect mouth condition, residence time, water chemistry and biological community structure over time periods ranging from annual to decadal. This pattern of varying hydrologic function and ecological services as a function of estuary state was observed by Clark and O'Connor [17] in their investigation of intermittent estuaries along the California (USA) coast. Jacobs et al. [31] provides one of the few classification systems that account for temporal dynamics by using geologic origin, exposure to littoral process, watershed size and runoff characteristics as the basis of a conceptual model that predicts likely frequency and duration of estuary mouth opening. Their system also includes general management recommendations related to both estuary class and status.

Advancing a classification system to inform ecological flow requirements for estuaries should build on past efforts by addressing the following research objectives:

- Directly relate estuary classes or types to susceptibility of changing inflow patterns including aligning with hydrologic regimes with ecological response across different points of the annual and interannual hydrograph;

- Include a consideration of the role of groundwater discharge in the function of certain estuary types;

- Use the classification system to directly relate physical drivers to biological response variables and identify key knowledge gaps in the physical- biological linkages;

- Identify flow management measures that may be most important to different estuary classes/types.

\section{Drivers and Forcing Factors: Considerations for Evaluating Hydrologic Changes}

The driving forces affecting estuary function can be grouped into those of watershed origin (river inflow) and those of a marine origin (waves and tides). This also aligns with the classification of estuaries based on the influence of wave, tide and river energy [33-37]. Critical research gaps exist in our understanding of both individual forcing factors and in how the two interact to affect estuary function (Figure 1). Sensitivity to flow modification can be discerned based on the relative dominance of tides, waves, and river flow [5]. At the extremes, an estuary can be considered a tidal embayment, a back-barrier wetland, or a river-dominated outlet with little marine influence. Most estuaries also change between physical states in response to changes in the key forcing parameters driven by seasonal cycles in the ocean and watershed. Physical states are typically associated with forcing parameter dominance, e.g., closed mouth conditions are associated with high wave forcing. While marine-dominated or brackish systems are at least partially forced by tidal action $[38,39]$.

\subsection{Watershed Forcing}

River inflow is a major factor that maintains open mouth conditions in wave-dominated TCEs $[15,18]$. It is often the only driving force that maintains the mouth in the open state as tidal flows are limited as a result of constricted mouths and small surface area. These systems are very sensitive to stream flow reduction and a small change in runoff can modify the period of mouth closure [40,41]. Permanently open estuaries, especially those along macrotidal coasts, are less sensitive to flow reduction, because the runoff and/or tidal flows are high enough to maintain open mouth conditions throughout the year, even during 
drought periods. However, changes in river inflow may influence even their longitudinal and vertical salinity structure and other mixing processes.

Quantifying relationships between changes in river inflow and estuary state and function is often challenged by data limitations. Measured or modeled hydrological time series need to be as long as possible to capture variability in flow and the magnitude and duration of extreme events such as droughts and floods. This is particularly important for temporarily closed estuaries, where, understanding the connection between changes in flow and biological response may be confounded by substantial lags ( $>4$ weeks) associated with high water retention times. The greater the flow variability, the longer the record needs to be, especially where there is significant variability within seasonal flows and between years $[42,43]$. Historically hydrological models were developed to identify opportunities for water resource development. Following engineering principles little effort was made to accurately predict low flows as they generally make up a small component of the mean annul runoff (e.g., $<20 \%$ ) and are technically challenging to predict in data poor environments $[43,44]$. However, as the science of environmental flows has been evolving, a range of important flow components that influence estuary function have been identified that need to be accurately determined for inclusion in environmental flow assessments (Table 1). These key aspects of hydrological forcing include magnitude and duration of discharges, shifts in the timing of seasonal inflows, changes in the frequency and intensity of events (floods and droughts) and the overall rate of change in flows. The flow components described in Table 1 vary in temporal scale from seasonal to decadal, however the effect of changes to these flow components is also influenced by the fluctuating water level at the ocean boundary on much shorter temporal scales varying from hours (e.g., tidal fluctuations) through to seasons (e.g., storm surges). Moreover, not all estuaries are equally sensitive to flow, e.g., a small estuary receiving abundant freshwater flow from a large catchment may respond similarly to a broad range of seasonal low and high flows, while a larger estuary subjected to similar freshwater flow inputs may respond with a marked difference in salinity and flushing regimens varying between a full salinity gradient state in the high flows to marine dominated in the low flows. Environmental flow assessments should be simulated at hourly or daily time steps to accurately predict flow variability, to predict the magnitude and duration of freshettes and floods, and to incorporate the interaction between riverine hydrological forcing and high frequency ocean water level fluctuations.

Table 1. Flow components characterizing the hydrological profile and associated ecological functions and ecosystem services of estuaries based on $[15,43,44]$.

\begin{tabular}{|c|c|c|c|}
\hline Flow Component & Temporal Scales & $\begin{array}{l}\text { Ecological Function Effects If Flow Component } \\
\text { Is Modified }\end{array}$ & $\begin{array}{l}\text { Ecosystem Services Effects If } \\
\text { Flow Component Is Modified }\end{array}$ \\
\hline $\begin{array}{c}\text { Cease to flow periods (natural or } \\
\text { due to abstraction) } \\
\text {-Onset of no flow period } \\
\text {-Duration of no flow period }\end{array}$ & Seasonal & $\begin{array}{l}\text { Increase in salinity, hypersaline conditions } \\
\text { Increase in the occurrence and duration of } \\
\text { mouth closure } \\
\text { Low water levels in systems that close to the sea } \\
\text { (decrease in water column depth) } \\
\text { Decrease in open water area } \\
\text { Soil salinization } \\
\text { Localized die-back of riparian vegetation } \\
\text { Loss of marine connectivity in estuaries that close } \\
\text { to the sea }\end{array}$ & $\begin{array}{l}\text { Reduced recreational appeal, } \\
\text { reduced coastal erosion control, } \\
\text { reduced water quality benefit, } \\
\text { reduce/collapse of nursery } \\
\text { function }\end{array}$ \\
\hline $\begin{array}{l}\text { Low flow periods (especially } \\
\text { flows that facilitate salinity creep) } \\
\text {-Onset of low flow period } \\
\text {-Duration of low flow period } \\
\text {-Lowest flow month } \\
\text {-Average monthly flow } \\
\text {-Standard deviation of flow }\end{array}$ & Seasonal & $\begin{array}{l}\text { Salinity creep (when open) } \\
\text { Mouth closure in systems that close to the sea } \\
\text { (occurrence and duration) } \\
\text { Soil salinization } \\
\text { Loss of marine connectivity in estuaries that close } \\
\text { to the sea }\end{array}$ & $\begin{array}{l}\text { Degradation of water quality, } \\
\text { reduced anadromy/amphidromy } \\
\text { and seasonal rearing of } \\
\text { anadromous/amphidromous } \\
\text { species, reduce/collapse of } \\
\text { nursery function }\end{array}$ \\
\hline
\end{tabular}


Table 1. Cont.

\begin{tabular}{|c|c|c|c|}
\hline Flow Component & Temporal Scales & $\begin{array}{l}\text { Ecological Function Effects If Flow Component } \\
\text { Is Modified }\end{array}$ & $\begin{array}{l}\text { Ecosystem Services Effects If } \\
\text { Flow Component Is Modified }\end{array}$ \\
\hline $\begin{array}{c}\text { High flow periods } \\
\text {-Onset of high flow period } \\
\text {-Duration of high flow period } \\
\text {-Highest flow month } \\
\text {-Average monthly flow } \\
\text {-Rate of change in flows } \\
\text {-Standard deviation of flow }\end{array}$ & Seasonal & $\begin{array}{c}\text { Altered marine-estuary connectivity (open mouth) } \\
\text { Sediment scouring/deposition } \\
\text { Altered reset of water column salinity } \\
\text { Altered inundation aptterns for supratidal } \\
\text { vegetation } \\
\text { Altered recruitment signals in the marine } \\
\text { environment for invertebrates and fish }\end{array}$ & $\begin{array}{l}\text { Reduced costal erosion benefit, } \\
\text { reduced nursery and rookery } \\
\text { function, effects on migratory } \\
\text { waterfowl foraging, damage to } \\
\text { cultural resources }\end{array}$ \\
\hline $\begin{array}{c}\text { Freshets } \\
\text {-Frequency } \\
\text {-Duration } \\
\text {-Magnitude } \\
\text { Rate of change in flows (how fast } \\
\text { or how slow) }\end{array}$ & Annual & $\begin{array}{c}\text { Altered reset of water column salinity } \\
\text { Altered inundation patterns for supratidal } \\
\text { vegetation } \\
\text { Changes to cues for migratory species to move } \\
\text { from sea into estuary } \\
\text { Changes to recruitment signals for invertebrate } \\
\text { and fish }\end{array}$ & $\begin{array}{l}\text { Reduced nursery and rookery } \\
\text { function, effects on migratory } \\
\text { waterfowl foraging, reduced } \\
\text { anadromy/amphidromy and } \\
\text { seasonal rearing of } \\
\text { anadromous/amphidromous } \\
\text { species }\end{array}$ \\
\hline $\begin{array}{c}\text { Bankfull events (small floods) } \\
\text {-Duration } \\
\text {-Magnitude } \\
\text {-Rate of change in flows }\end{array}$ & $\begin{array}{l}\text { Small floods (e.g., } \\
\text { 1:2, 1:5, 1:10 year } \\
\text { return period)) }\end{array}$ & $\begin{array}{c}\text { Altered scour of main channels of sediment, } \\
\text { accumulated organic matter and sediment } \\
\text { pollutants } \\
\text { Altered inundation of riparian vegetation } \\
\text { Changes to recruitment signals for invertebrates } \\
\text { and fish }\end{array}$ & $\begin{array}{l}\text { Water quality degradation, } \\
\text { reduced nutrient cycling, reduced } \\
\text { nursery and foraging effects }\end{array}$ \\
\hline $\begin{array}{l}\text { Overbank flood events (major } \\
\text { floods) } \\
\text {-Duration } \\
\text {-Magnitude } \\
\text {-Rate of change in flows }\end{array}$ & $\begin{array}{l}\text { Major Floods } \\
(1: 10,1: 20,1: 50 \\
\text { and 1:100 year } \\
\text { return period) })\end{array}$ & $\begin{array}{c}\text { Altered scour of main channels and floodplain of } \\
\text { sediment, accumulated organic matter and } \\
\text { sediment pollutants } \\
\text { Altered reset of sediment } \\
\text { erosion/depositional cycles } \\
\text { Altered inundation of floodplain vegetation } \\
\text { Changes to significant recruitment signals for } \\
\text { invertebrates and fish }\end{array}$ & $\begin{array}{l}\text { Reduced costal erosion benefit, } \\
\text { reduced habitat effects, reduced } \\
\text { recreational appeal, } \\
\text { reduce/collapse of nursery } \\
\text { function }\end{array}$ \\
\hline $\begin{array}{l}\text { Droughts } \\
\text {-Occurrence } \\
\text {-Duration } \\
\text {-Magnitude }\end{array}$ & $\begin{array}{l}\text { Drought cycles } \\
\text { (e.g., 1:10 years } \\
\text { or } 1: 20 \text { year } \\
\text { return period) }\end{array}$ & $\begin{array}{l}\text { Increase in salinity, hypersaline conditions } \\
\text { Increase in the occurrence and duration of mouth } \\
\text { closure } \\
\text { Low water levels in estuaries that close to the sea } \\
\text { (decrease in water column depth) } \\
\text { Decrease in open water area or complete drying of } \\
\text { this area } \\
\text { Soil salinization } \\
\text { Disconnect from catchment } \\
\text { Die-back of riparian and submerged vegetation } \\
\text { Recruitment failure of invertebrates and fish }\end{array}$ & $\begin{array}{l}\text { Reduced recreational appeal, } \\
\text { reduced coastal erosion control, } \\
\text { reduced water quality benefit, } \\
\text { reduced nursery function, }\end{array}$ \\
\hline
\end{tabular}

Although the characteristics of estuaries are mainly influenced by seasonal base flows, floods also play a role in the longer term, e.g., in scouring and erosion of sediment and resetting the salinity regime in estuaries (Figure 2). The nature of the watershed characterized by rainfall, size, slope, vegetation, land-use practices; and the type of sediment source, determines the character of sediments discharged into the coast (e.g., predominantly fine or medium grained). Rivers that primarily drain coarse-grained rocks resistant to erosion will have considerably lower sediment yields with sediment largely being medium to coarse grained in nature. Large volumes of sediment can be removed in a very short time during major floods with 20-year return periods and higher. Smaller floods with 5- to 10-year return periods can sometimes also have a significant influence in physically confined estuaries. Floods therefore play a major role in the equilibrium between sedimentation and erosion in estuaries [45]. Research in estuarine and coastal sedimentary processes lags behind hydrodynamic and biological prediction capabilities, reflecting a need for focused research. Progress is hindered by the absence of long-term calibration data sets (i.e., estuary bathymetry, fluvial sediment loads) and a relatively young developing discipline. This provides multiple research opportunities to investigate the role of floods in the various types of estuaries, the rate of sediment accretion vs. sea level rise, estimating the synergistic/antagonistic impacts of dam development and resultant sediment trapping and flow 
modification in conjunction with changes in land-use, land-cover and flood regimes under a future changing climate.

Beyond surface flows, information on subsurface groundwater inflow and seepage losses through the beach berm is often lacking, or of low confidence. Globally, estuarygroundwater interactions are understudied, and models need to be improved to account for direct groundwater inflow into estuaries (with models often not providing input as a rate of flow). It should be noted that while simplified mass-balance models may work well in small estuaries, large more complex systems require detailed hydrodynamic modeling of mouth behavior and retention times to inform environmental flow assessment. Such modeling must be simulated at a time step and over a time period that allows the incorporation of both high frequency and low frequency hydrological and ocean forcing events.

Climate change is likely to accelerate ecosystem degradation in synergy with present pressures. There is a need to down-scale existing global/regional-scale models outputs [46] for application at the estuary watershed-scale, particularly for TCEs for which current spatial resolution of global models may be insufficient. Key vectors of climate change that should be considered for down-scaling include shifts in seasonal rainfall/snow-rain transitions and associated change in seasonal inflow, changes in magnitude and frequency of floods and droughts, and projected seasonal increases in terrestrial temperature regimes. This in turn can result in shifts in seasonal connectivity, loss of characteristic salinity regimes, change in habitat and shifts in spawning and migratory signals. Research is needed on how climate forcing affects hydrodynamic properties of estuaries and how changes to inflow patterns can influence estuary abiotic and biotic responses (Figure 1). For example, when does managing environmental flows exacerbate or mitigate changes due to climate forcing? Dynamic/conceptual models will need to be refined and/or developed to describe the biophysical cycles of different types of estuaries and to discern the role of climate variability over scales that influence abiotic and biotic processes, e.g., sediment cycles and biological diversity [47].

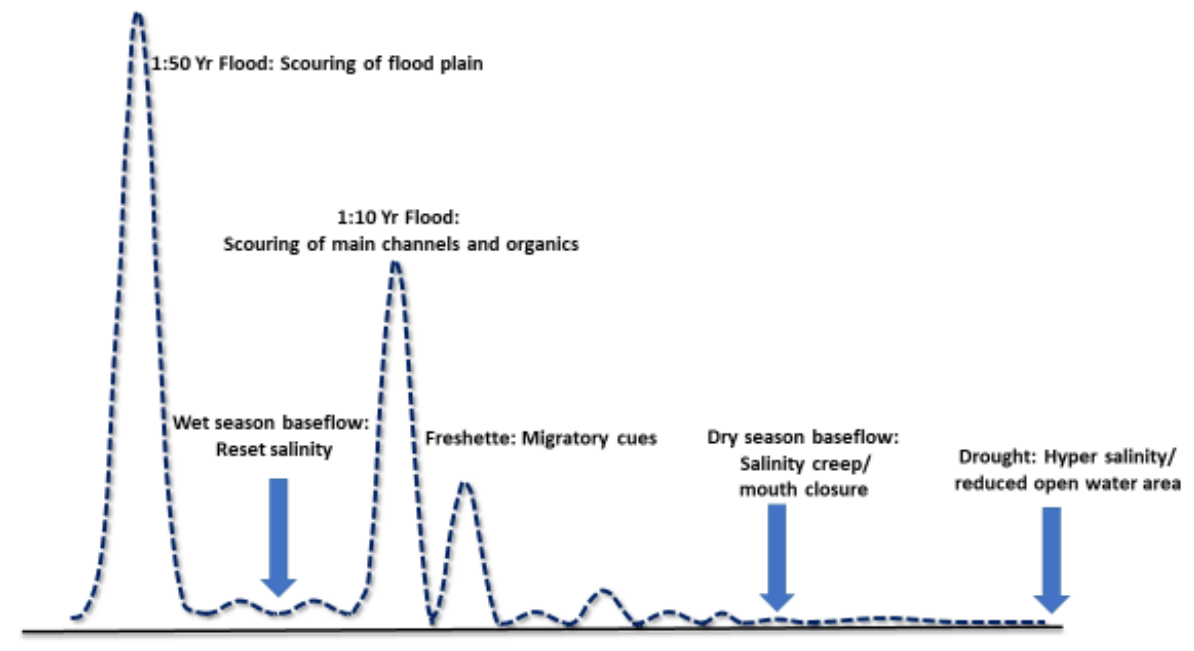

Figure 2. Conceptualization of various flow events, their frequency and functional significance that should be considered in the development of environmental flow assessments.

\subsection{Ocean Forcing}

The importance of ocean forcing in TCEs is a function of their size, depth, position relative to high tides, and the structure and closure frequency of the mouth (Figure 1). Shallow, wave dominated estuaries are the least studied and arguably the most vulnerable to global change because of their relatively small volumes, high water retention times, perceived low social value and lack of scientific understanding. For this type of estuary, the flow regime needed to maintain an open mouth is strongly dependent on sediment availability and wave conditions [15]. For example, baseflow requirements would be significantly higher for estuaries situated along high-energy coastlines, such as those found 
along the South Africa, Australia, California (USA) coast. In general, the stronger the wave action in the mouth, the greater the vulnerability to mouth closure.

Standard 2D and 3D modeling approaches, such as coupled hydrodynamic-wavesediment transport modeling or traditional 'equilibrium' modeling, in many cases does not resolve the relatively fast and complex changes in the mouth morphology over long time scales [5]. Most standard models used to simulate hydrodynamics were developed for larger estuaries, with a focus on navigation, and are insensitive to change in small systems that close to the sea. Progress in numerical modeling see [48] has made advances possible in predicting changes in mouth morphology. However, these analyses often require prohibitively large effort (e.g., calibration of multiple parameters based on long time-series datasets) and resources to evaluate, making it difficult to implement in routine environmental flow assessments. Furthermore, the unique characteristics of each estuary make it nearly impossible to apply sediment and mouth dynamics models without extensive site-specific validation. For example, estuaries with perched mouths behave differently than muted tidal or fully tidal systems. Clever use of remote sensing technologies may alleviate some of the resource-intensiveness associated with data collection for modeling, however novel technologies and improved ways of using existing technologies will be required to realize this benefit. Behrens et al. [5] call for a simple time-series model approach, called a "quantified conceptual model (QCM)", which calculates estuary water balance in conjunction with a simplified parametric model of the mouth and beach. Such models can bridge the gap between resource intensive numerical modeling and the need for repeatable results in flow sensitivity analysis.

Regional sediment budgets affect the rate and duration of mouth closure, which in turn influences the relative effect of changes in freshwater inflows. Regional sediment flux and nearshore movement are seldom assessed in the context of cumulative effects of sediment trapping by large dams, impact of local coastal structures and dredging, and extractive activities such as coastal mining. Once sediment of terrestrial or fluvial origin is deposited in the coastal zone these sediments are subject to coastal processes and become part of the marine sediment budget. These marine sediments can once again be transported back into estuaries. Therefore, over long timescales, the amount and character of marine sediment transported into estuaries is often ultimately determined by the larger rivers within a region. This also implies that the availability of marine sediment is likely to be affected by progressive changes in the watersheds that feeds the coast and argues for regional sediment transport analyses to support environmental flow assessments.

Sea level rise will drive changes in critical estuarine processes such as sediment dynamics, mouth state, and salinity regime shifts; with associated responses in biotic processes and patterns, e.g., biotic habitat structure, changes in recruitment, and community composition [18]. Sea level rise can either counteract the reduction in runoff to an estuary or exacerbate the effect depending on the size of the estuary, sediment availability, and wave energy near or at its mouth. Significant research effort is currently underway to understand the impact of sea level rise on estuary habitats [49] with a key requirement being the identification of habitat accommodation space using models such as the Sea-Level Affecting Marshes Model (SLAMM) (Warren Pinnacle Consulting, Inc., Waitsfield, VT, USA, e.g., [50]. However, many of these models neglect or underestimate processes such as marsh accretion and subsidence. Research is needed on more dynamic predictors of the impact of sea level rise on habitat and associated biotic responses. In closed hypersaline estuaries sea level rise and an increased frequency of overtopping of sand bars will dilute salinity [24]. While most studies focus on surface elevation change in salt marshes of uniform salinity, there is a need for elevation studies in marshes across broad salinity regimes and differing geomorphic positions to assess potential risk to brackish, oligohaline, and freshwater tidal wetlands because of submergence under future sea level rise [51].

The frequency and magnitude of severe weather events such as tropical cyclones appear to be on the increase globally [46,50]. While Komar [52] and Ruggerio et al. [53] provide evidence of increasing storm intensities in the Northern Hemisphere, more research 
is needed in the Southern Hemisphere on trends in storminess to support predictions of estuary change. An increase in storminess could increase ocean forcing and thus the occurrence of mouth closure and the transport of marine sediment into estuaries. Estuaries along an exposed, sediment rich, microtidal coastlines would be more likely to close, which may increase environmental flow allocations in the future. Site specific research is needed to predict the possible impact of increased storminess on estuaries using measured data and models [54,55]. Coastal storms can also increase water levels and salinity well above established norms. These in turn can cause ecosystems shifts in more freshwater dominated systems. In addition, research is also urgently needed to better understand the effects of decadal oscillations (El Niño-Southern Oscillations (ENSO) and Pacific Decadal Oscillation $(\mathrm{PDO})$ ) on estuarine abiotic and biotic process, given that climate extremes often determine the nature of estuaries. For example, Francisco and Netto [56] found that the effects of such oscillations are influenced by the spatial scale and the geomorphology and zonation of each estuary, with tide dominated estuaries more sensitive to PDO and river dominated system sensitive to ENSO. Systematic monitoring of changes in mouth closures, water levels and salinity during ENSO events can provide critical insight into potential future conditions under warmer ocean conditions that may be represented during current ENSOs [57].

A deeper understanding is needed on how changes in freshwater inflows will interact with changes in ocean forcing, and how this will influence decisions about setting environmental flow requirements:

- Downscale outputs of global climate models and embed in standard hydrological models, including the impacts of higher temperatures and increase evaporation. Results needs to be placed-based, with the calculation of key flow indicators automated.

- Conduct integrative research on synergistic effects of a changing climate. What would happen if freshwater flow is reduced, but sea level increase?

- Develop sediment budgets under current and future conditions and assess changes in sediment processes because of both ocean and watershed forcing at local and regional scales to better understand effects on estuary morphology and resilience to climate change.

- Improve understanding of the role of extreme events (floods, coastal storm and storm surges) and decadal oscillations on estuarine processes, and how these events will be affected by climate change.

- Improve efficiency of models to capture both extreme and low intensity (high frequency) runoff events and dynamically couple these hydrologic patterns with changes in abiotic processes and biotic responses over long time scales.

- Improve remote sensing technologies and methods relevant to estuarine hydrographic and hydrologic data collection and data integration into numerical modeling processes.

\section{Ecosystem Function and Threats: Effects of Hydrologic Alteration}

Temporarily closed estuarine habitats and their associated ecological functions generally follow the salinity gradient from freshwater to brackish to the ocean (Figure 3). Salinity is determined by estuary morphometry, river flow and ocean influence, which varies temporally with river flow and precipitation patterns [58]. Extreme variability of salinity, temperature, and turbidity gradients over multiple time scales (tidal cycles to interannual) make estuaries naturally stressful environments. These stresses can be easily exacerbated by anthropogenic effects such as altered freshwater inflow. These effects combined with the prediction that Mediterranean climates are becoming warmer and dryer [59,60], make TCEs particularly susceptible to permanent ecological shifts associated with climate change [24]. Significant research gaps exist related to quantifying ecosystem functions in TCEs and to developing tools that relate hydrologic stress to changes in ecosystem function (Figure 1). 


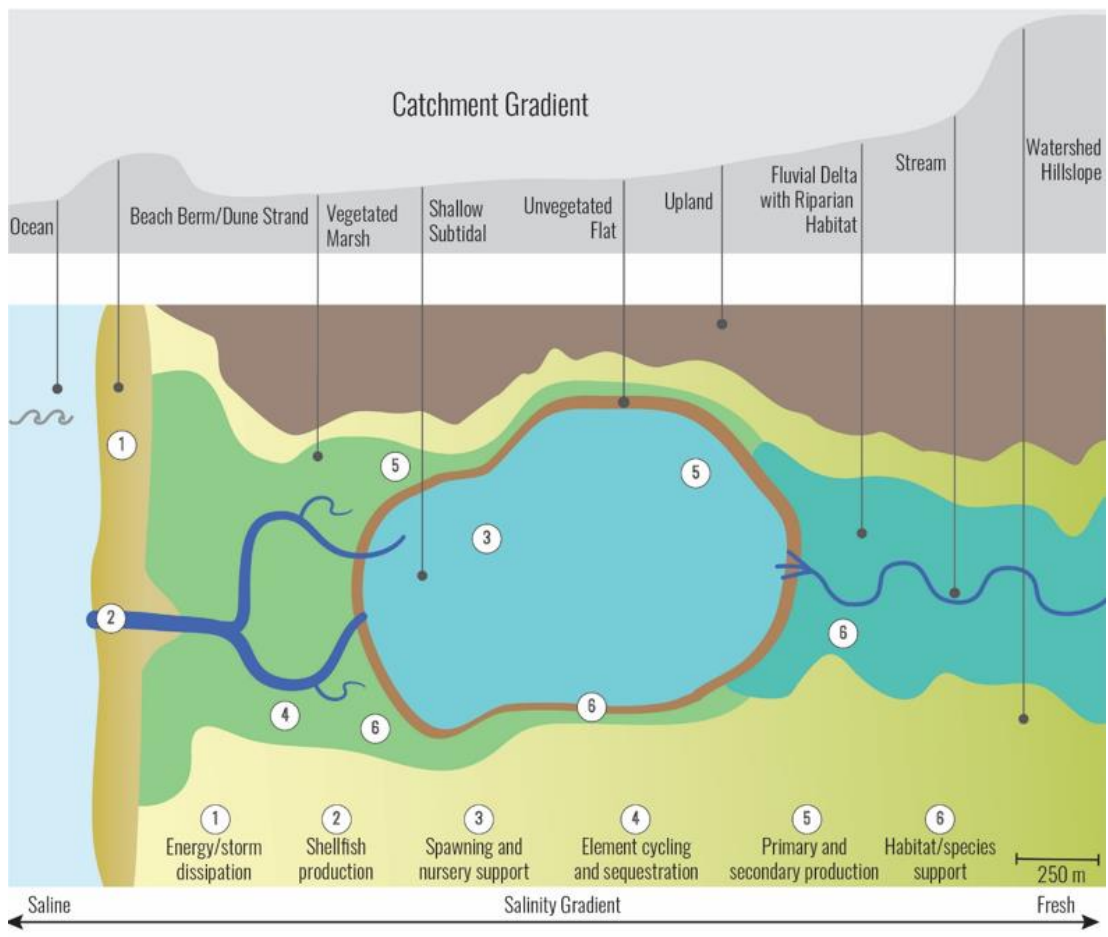

Figure 3. Schematic diagram of an estuary depicting major habitat types and associated functions along a characteristic salinity gradient. Numbers correspond to locations where functions listed at the bottom are expected to occur.

\subsection{Functions}

Estuaries support a wide array of taxa that both support and are supported by linked processes. They are typically nutrient rich, which is a product of high inputs from both allochthonous and autochthonous sources. Autochthonous sources of primary production include phytoplankton, macroalgae and vascular plants, e.g., seagrass beds, salt marsh and mangroves, which provide an important food source for secondary consumers such as zooplankton and suspension feeders. This process fuels secondary production by converting organic material into higher trophic levels, an important link in food web dynamics and energy transfer [61]. Allochthonous nutrients are naturally transported into estuaries through freshwater inflow, but also have anthropogenic contributions such as urban and agricultural runoff. Nutrient inputs tend to be high, but estuaries are able to act as a net sink, with phytoplankton playing a major role in nutrient cycling and removal [62].

Vascular plants provide shelter and protection for free swimming fish and crustaceans (nekton) as well as benthic invertebrates (infauna). By supporting nekton and infauna taxa, the system provides a food source for birds and other wildlife, including endangered and protected species, that rely on estuaries for all or part of their life history.

Estuaries provide important spawning and nursery grounds for commercially important fish and shellfish species and a migration route for diadromous fish. Although species diversity differs between biogeographic regions and estuary type $[63,64]$ the majority of fish species in TCEs are comprised of juveniles of marine spawning fish $[63,65]$ which exploit favorable conditions (e.g., food, shelter) that promotes survival. Adult fish also utilize the estuarine environment either as residents or transients (marine and freshwater) [64].

Commercially significant shellfish (bivalve filter feeders) species [66] rely on these systems for all or part of their lives. They rely on high amounts of primary production unique to estuaries and because of their ability to filter large amounts of seawater (e.g., oysters: [67]) are vital to ecosystem health and water quality, by controlling phytoplankton growth [68].

These systems also support physical features that can absorb and protect land through the dissipation of storm derived wave action [69], freshwater inflow control and regulation 
of flooding and stabilization of sediment to control erosion [70,71]. In addition, these systems can ameliorate the impacts of sea level rise (SLR), through salt marsh accretion as long as rates are higher than that of SLR itself [72].

The numerous interlinked component functions of TCEs make it complex to assess functional health. A holistic set of tools, procedures and analysis frameworks that focus specifically on TCE functioning is necessary for effective environmental flows management.

\subsection{Threats}

The health of estuaries is fundamentally associated with freshwater inflow, which includes the magnitude of flow, as well as the timing, frequency and duration of flow events. These dynamic aspects of flow regime play an important role in mouth closure [31], with low flows being associated with closed mouth state and high flows with open mouth state [15]. Flow alteration in the surrounding watershed from, e.g., dams, channelization, urbanization and abstraction, can have a substantial impact on estuarine mouth dynamics, which in turn can influence biotic processes and ecosystem functions and services (Table 1).

Decreased freshwater inflow can impact the defining features of TCEs by prolonging water residence times and influencing mouth closures. Conditions can become hypersaline $[24,65,73]$ which can impact the biological communities, cause changes in species composition and declines of fish, submerged vegetation and salt marsh habitat (Table 1), benthic macroinvertebrates, zooplankton, mollusks and crustaceans $[15,58,74]$ as well as mass fish mortality events (e.g., [64]). Systems in this condition can also induce hyposalinity [32] during large freshwater flow events, resulting in fish mortality [75] as well as a shift in freshwater species dominance [15]. Species that spawn in TCEs such as fish and invertebrates are adapted to the naturally stressful environment; however, further decreases in flow will necessitate species to adapt to increased temperature and salinity. For specialist native species this may be challenging, the physiological impacts of which are poorly understood [24] and may lead to invasions by non-native temperature and salinity tolerant species.

Hypoxic and anoxic conditions are common in some salt-wedge systems, such as the Swan River estuary in Australia [76], that limit vertical mixing of upper and lower layers producing stratified conditions. Here, reduced freshwater inflow promotes eutrophication and associated depleted oxygen levels, which can change biotic characteristics of fish [77] and zooplankton [58] communities. In addition, increased sediment movement can impact water quality and nutrient influx [78]. In these systems, the magnitude of freshwater inflow, and hence flushing, can help moderate oxygen depletion [79].

Harmful algal blooms are another product of eutrophication due to low tidal energy and sediment transport, which make TCEs sensitive to increases in nutrient levels, resulting in large plankton blooms $[23,24,80]$. When high levels of naturally occurring dinoflagellates and cyanobacteria are present in blooms, this can result in mass fish kills and have serious consequences for human health through diarrhetic and paralytic shellfish poisoning $[81,82]$. Understanding phytoplankton dynamics is challenging because of the multifaceted influence of many biochemical processes $[83,84]$ and therefore the ability to model and predict events is highly complex and data intensive (e.g., [85]). These processes are likely exacerbated by changes in freshwater inflows, which should be incorporated as new models are developed.

Mouth state plays an important part in land-sea connectivity which impacts quality of important habitat. Changing mouth state because of altered freshwater inflow, can amplify eutrophication, hypoxic/anoxic conditions and hyper/hyposalinity effects [41]. Temporarily open/closed estuaries are generally more productive when open, because of mixing and exchange of biochemical processes, with the exception of perched estuaries that are more productive when closed, which support higher quality nursery and spawning grounds [86]. The loss of connectivity results in the inability of various species to move between freshwater and the ocean, e.g., juvenile marine fish reaching nursery grounds, interrupted upstream and downstream migration of freshwater species with marine life 
stages. Diadromous fish also rely on changes in temperature and stream flow as cues for migration timing and direction. Loss of connectivity may not only hamper their ability to migrate physically but may also impact genetic diversity [87]. Environmental flows can support recruitment by ensuring an open mouth state during key migration and breeding times [15].

When the closed mouth state is prolonged, reduced tidal influence results in loss of key habitats such as the intertidal zone, salt marsh and mangroves. Systems in closed mouth state are also susceptible to nutrient loading which often promotes rapid growth of phytoplankton $[15,88]$ potentially leading to further eutrophication and hypoxia. The prolonged residence times and limited scouring by high flows also promote the accumulation of pollutants and contaminants [15]. Contaminant related toxicity can increase because of higher concentrations and water temperatures associated with reduced freshwater input due to diversions, climate change or other sources [89].

Hypersaline conditions are typically present during dry periods during which, low tidal exchange, high temperatures and long residence times result in evaporation rates exceeding rates of freshwater inflow. Commonly, they are observed in semi-arid/arid Mediterranean climates that experience hot, dry summers and temporarily closed mouth systems [90] but are also observed during open mouth state in stratified systems [91]. Such systems exhibit distinct attributes, albeit with potentially detrimental consequences, e.g., mouth state frequency and duration influenced by low flows, phytoplankton growth from increased nutrient cycling and species recruitment failure of from habitat loss. Increased understanding of how to best manage freshwater inflow has potential to reduce impacts associated with altered rates and durations of mouth closure, and its effect on salinity and toxicity.

The following considerations can help broaden our knowledge to further understand, measure and predict estuarine functional response to environmental flows:

- Maintain long-term assessments to measure the health of rooted macrophytes, e.g., salt marsh/mangrove/macrophytes cover as measures of habitat and shoreline stabilization functions as well as directly measuring the impact of a stressor on those functions.

- Develop causal assessments tools that can provide information on the probable cause of an altered system and have the potential to determine what component of the flow regime is influencing an ecological function, e.g., the magnitude, or the timing of high flows.

- Establish relationships between salinity, turbidity, temperature, and nutrients and health and vigor of plant and animal communities through long-term monitoring of multiple types of TCEs.

- Improve tools that directly measure function, e.g., rates of primary productivity, as a component of the functional equivalency approach [92]. Establish meaningful thresholds to determine the difference between healthy and unhealthy systems.

- Develop tools to better evaluate cumulative and interacting effects on functions. For example, increasing inflows in a system may increase nutrient flushing and oxygen exchange, but may potentially have detrimental consequences involving reduced nutrient cycling and primary production on other aspects of the system.

\section{Establishing Expectation and Desired Conditions}

The success of environmental flow assessments relies on having clearly articulated and focused desired outcomes. Desired outcomes establish shared expectations among stakeholders with often disparate interests and determine the metrics and assessment methods against which success will be measured. The importance of establishing an agreed upon set of expectations was highlighted by Elliott et al. [93] in a review which noted that poorly defined objectives has repeatedly led to failures of ecohydrology restoration and management projects.

Desired outcomes have traditionally focused on ecological endpoints for which metrics are relatively well established for assessing success, for example temporal changes 
in species richness, abundance, or community composition, or functional diversity can indicate successful management of environmental flows [15,18,41,94]. South Africa, for example, set the reference condition at about 100 to 150 years ago before there were significant anthropogenic impacts in the landscape or catchments. Similarly, in Victoria, Australia, the goal of environmental flow assessment for estuaries is to maintain the "major ecological features and functioning of that system prior to European settlement" [95]. One aspect of functioning that is often overlooked is the temporal variability in hydrology and processes within estuaries, for example multi-year scale changes in inflows associated with climatic features such as the El Niño La Niña Southern Oscillation or the seasonal patterns of usage of nursery habitat by fish. Additionally, our understanding of the links between flow and abiotic and biotic states is highly variable between estuaries. Process-based endpoints may, therefore, be more useful than state-based endpoints, particularly for hydrological processes that generally regulate the structure of biotic communities [93]. In many cases, there may be a tension between different ecological processes affected by seasonal differences in freshwater inflows. Protection of high flows may be beneficial for maintaining estuarine morphology and may be impacted by changes in land use (which may also produce deleterious water quality effects; [96]). In contrast, reduced inflows may increase stratification and reduce water quality $[15,96]$. The choice of ecological endpoints therefore determines which flow components are preferentially protected or enhanced as a result of environmental flow management and the multiple temporal scales at which estuarine processes occur should be considered when choosing these endpoints.

Desired ecological endpoints for environmental flow management are usually based on the present condition or a perceived reference condition and its importance for conservation status and/or other important resources uses [18]. While assessing the present condition and determining the current conservation status is relatively straightforward, establishing suitable past reference conditions for ecological endpoints provides important context, but can be hampered by a lack of long-term data. One promising approach is the use of paleoecology or historical ecology as recently demonstrated by Stein et al. [97] who established a reference point for the past extent and type of coastal wetlands in California using historical topographic and navigation maps. Historical reference points such as these can be used as a target for restoration or can help inform trade-offs between the desired ecological state and other, possibly competing, benefits that may be expected under different hydrologic regimes.

Progress towards achieving desired outcomes can be slow depending on the timescales of the ecological processes that have been altered by changes to the flow regime and the inherent variability of the system. Ideally, we would have reference points to use as sign posts that recovery is occurring along a trajectory to the desired endpoint. Interpreting ecological metrics as evidence of progress along a recovery trajectory remains confounded, however, because degradation and recovery do not always follow similar trajectories [98]. Instead, the path to recovery may take a different route than expected based on the path of degradation to the current state $[99,100]$. Likewise, it may be difficult in some systems to determine whether the desired ecological endpoint is achievable, because of landscape constraints that affect resilience and the potential for multiple stable states [94]. In less impacted systems hysteresis and multiple stable states may influence the desired outcomes of environmental flow management through consideration of the reversibility of future impacts of changes to the flow regime. In South Australia, for example, environmental flow releases in the Murray River are undertaken partly to maintain high enough water levels in the Lower Lakes to prevent the exposure of acid sulphate soils which would tip the estuarine lakes from one stable state to another undesirable stable state (acidified water, mobilized toxic metals), as has happened in past droughts [101,102]. Pelletier [94] points out that the presence of multiple stable states may not be recognized until after an ecosystem has tipped from one to another. Te Waihora/Lake Ellesmere in New Zealand provides one such example, having transitioned from a macrophyte dominated environment to an alternate stable state of high turbidity and phytoplankton dominance, despite restoration 
efforts [103]. In such situations the desired ecological conditions and processes may be out of reach regardless the changes to the flow regime.

Desired outcomes must also account for changes in hydrologic forcing because of climate change (discussed above) which may profoundly influence what is reasonable and achievable. Scanes et al. [104] found that the changes to estuaries as a result of climate change are occurring an order of magnitude faster than global models predict, with systems that have a limited connection to the ocean, such as temporarily closed estuaries, most affected. Doughty et al. [105] found that small intermittently closing estuaries along the southern California (USA) coast will be almost entirely lost with $1.7 \mathrm{~m}$ of sea level rise. The quantity and timing of freshwater inflows into estuaries is likely to change, although the direction and magnitude of changes will vary from place to place. For example, in New Zealand the magnitude of inflows is predicted to generally decrease in North Island estuaries and increase in South Island estuaries [106]. However, in New Zealand, the mean change is not a good proxy for the effect on flow variability. In addition, predicted sea level rise varies globally and may exacerbate the effect of reduced inflows into some estuaries, changing the morphology of the estuary and hence many of the physical processes [105]. In addition to changes in sea level, Australian estuaries are warming and acidifying faster than predicted by global climate modeling, with lagoons and rivers most affected [104]. The same study found that temporarily closed lagoons are also freshening because of increasing periods of mouth closure, while estuarine rivers are salinizing as a result of reduced inflows. Gillson [107] notes that social and economic behavior may also change as a result of changing climate, with interacting effects on estuarine fish species that are sensitive to reduced inflows under a changing climate. Temperature effects will also likely change the nature of estuarine communities, both through species temperature tolerance ranges and by affecting spawning and migration times of flora and fauna [108]. Overall, climate change effects will alter the hydrology and hydraulic gradient of estuaries at a range of temporal scales, as well as related environmental variables like temperature, and the complex interactions of these effects should be considered in setting desired conditions for environmental flows assessments. The incorporation of climate change impacts into decisions about the desired outcomes for environmental flow assessments would benefit from the development of a framework that would improve consistency between how these factors are considered in different locations and by different jurisdictions.

Establishing regional goals that transcend individual estuaries is also critical for ensuring resilience and providing that an appropriately representative set of estuaries persists under changing conditions. TCEs are often very small by global scales, thus resulting in a perception that individual systems are not of high importance or value. However, networks of these smaller systems play an important role in estuarine-coastal connectivity and inter-estuary recruitment as they collectively comprise significant estuarine area in a region and function as waypoints $[41,109,110]$. Stein et al. [97] note that restoration of small coastal lagoons and estuaries has traditionally been given lower priority because they lack the size, diversity, and charisma of larger coastal wetlands. However, the remnant wetlands along urbanized coastlines are often much smaller and more constrained than they were in the past. Emphasizing a series of smaller but intact wetlands that collectively provide desired habitats and functions rather than attempting to create a few large idealized estuaries within a smaller than historical footprint may ultimately be more sustainable and achieve the goals of compatibility with landscape and hydrologic drivers. Unfortunately, there is little research available to guide planners and resource managers on how to incorporate connectivity into environmental flow studies. The health of individual estuaries contributes to overall resilience of networks of estuaries along a coast; however, we currently lack an understanding of the degree to which the health of adjacent estuaries influences each other [41]. More research is needed (e.g., mark and recapture, telemetry and genetic studies) to support the development of guidelines and ensure that these highly vulnerable estuaries are not seen as sacrificial in the setting of targets for desired states in water allocation processes [41]. 
Beyond ecological endpoints, social and cultural values should be considered when establishing desired conditions. Such values can be tangible or intangible; for example, the role of particular waterbodies in creation stories, or mahinga kai (the gathering and use of food resources [111]). The inclusion of cultural values brings an extra dimension to the consideration of the desired outcomes of environmental flow management. To achieve culturally desirable outcomes, we must understand not just flow-ecology relationships, but ecology-culture relationships, as well as direct flow-culture relationships. Contrary to what is often assumed, indigenous cultural values may be at odds with a western science-centric ecological perspective [111]. For example, in New Zealand, mahinga kai expresses the Māori cultural value of food collection. Improving or maintaining mahinga kai may necessitate a different flow regime than would a western science-centric ecological outcome [111,112], especially if this involves managing the flow regime to promote the prevalence of particular species over others (e.g., reducing the frequency of flushing flows to favor species which prefer higher salinity).

Environmental flows are expected to support complex combinations of benefits (social, cultural, economic, ecological) in all environments, not just estuaries [113]. Estuaries, however, can be particularly contested spaces due their value from ecological, economic, social, and cultural perspectives. Establishing robust methods for trade-offs between competing values is an important step towards establishing a consensus around desired outcomes. Brown et al. $[114,115]$ describe two approaches to determining desired outcomes-prescriptive vs. scenario based. In a prescriptive approach, there is an agreed level of ecological condition that must be maintained, and a flow regime is prescribed to support this. They recommend this approach in low-conflict environments. The alternative, which they consider appropriate for environments where the conflict between ecological conditions and other valued objectives is high, is to consider a range of scenarios and determine the trade-offs for each scenario between ecological condition and other desired outcomes, such as consumptive use, cultural values, etc. This allows for negotiation based on preferred futures and fits within the paradigm of integrated water resources management (see Conclusion and Recommendations, Section 8). Resolving the balance of which competing values have greatest influence over the desired outcomes varies globally. For example, the Water Framework Directive in the European Union cites "good ecological condition" [116,117], whereas in New Zealand the policy framework includes communitydriven identification of "values", governed by an overarching principle of "te mana o te wai" (the intrinsic value of the water in the water body as the first objective) [118]. In South Africa trade-offs are facilitated by a multi-criteria decision analysis that considers predicted future resource condition, loss and gains in ecosystem services, macro-economic gains and potential for generating jobs through water resource development [41]. These are evaluated for a range of water resource development scenarios in a public-private stakeholder environment before the ultimate decision is made by the state as custodian of water resources in the county [119]. The outcome often includes provision for a 'Water Reserve' (defined as the quantity and quality of freshwater required to satisfy basic human needs, considering both present and future requirements) to be determined prior to the allocation of water for agriculture or industrial purposes. Similarly, California (USA) has recently begun considering the establishment of 'ecosystem water budgets' based on the total volume of water required to satisfy environmental flow needs taking into account ecosystem management objectives, current water uses, and institutional arrangements [120]. Each of these approaches has merit; developing a mechanism for sharing experiences and lessons learned from seemingly disparate approaches would enhance the practice of objective setting for environmental flow assessments globally. Similarity conservation planning of aquatic resources and fisheries management are treated as separated from environmental flows assessments, while they should be seen as central to the allocation process and the setting of the desire state. Especially as some flow reduction impacts can be off-set or amplified by resource use activities such as fishing. 
There are a number of specific areas where additional research could improve the way that desired outcomes are determined for environmental flow assessments, including:

- Improve ways to identify and quantify trade-offs between competing values in the establishment of the desired conditions and end points. Develop a mechanism for sharing experiences and approaches globally on resolved trade-offs and potential conflicts in endpoints.

- Develop tools and approaches to better incorporate cultural, social, and indigenous values into environmental flow assessments.

- Develop methods for identifying multiple reference points to create a trajectory of recovery from past to present to desired future condition, considering multiple domains including morphological, ecological and social, and incorporating the differences between trajectories of degradation and trajectories of recovery.

- Incorporate paleoecology and historical ecology to identify historical ecological states and processes and to establish reference conditions.

- Improve methods for incorporating climate change effects into decisions about desired outcomes. This should include consideration of how climate change affects the ability to achieve desired end points, including the effects on freshwater inflows, marine forcing, temperature, morphology, and ecological processes.

- Improve ability to understand connections between clusters or networks of TCEs and how changing flow conditions influence regional connectivity and function.

\section{Monitoring, Assessment and Adaptive Management}

The long-term success of environmental flow management programs, similar to all management programs, relies on the ability to track progress and change over time, and to adjust responses based on knowledge obtained through past practices using an adaptive management approach (Figure 4). Committed long-term monitoring is also the best way to produce the data necessary to detect trends, understand stress-response relationships, develop and improve assessment tools, and improve model calibration. Past research has addressed elements that should be included in monitoring programs [121,122]; however, there are few examples of successful implementation of long-term monitoring and adaptive management [123].

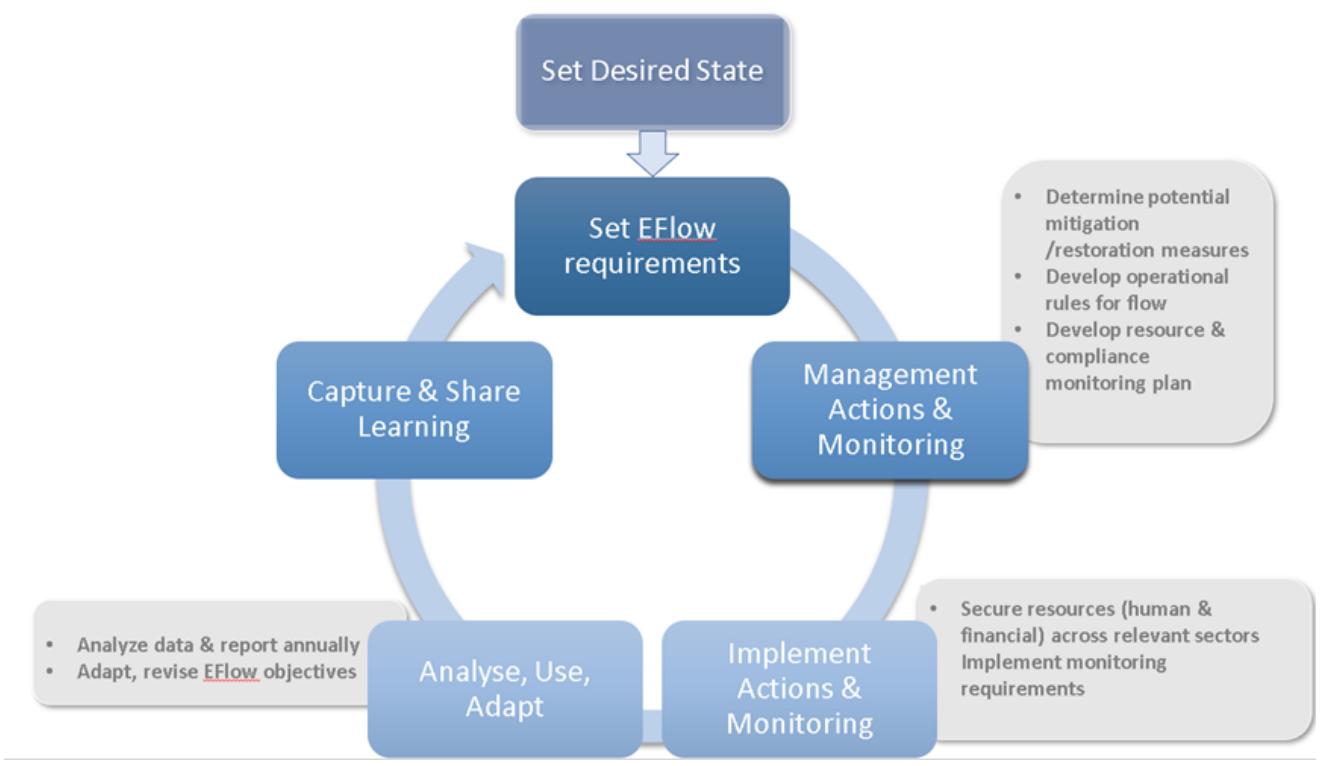

Figure 4. Process for implementing estuarine ecological flows in an adaptive management cycle.

The challenge of an adaptive management approach is finding the correct balance between gaining knowledge to improve management in the future and achieving the best short-term outcomes based on current knowledge [124,125]. Sustained long-term 
monitoring requires establishment of clear objectives consistent with desired outcomes through a stakeholder process (see above); collection of appropriate data to establish causal associations between stress and response, management and response endpoints; development of assessment tools to support data interpretation by managers; and longterm commitment by monitoring and management entities to collect, analyze, store, and disseminate data and findings.

Monitoring objectives should be consistent with the desired outcomes established early in the process of developing environmental flows. Clear documentation of the rationale and basis of the desired outcomes will reduce the chances that adaptive management results in the unintended downward spiral of expectations often associated with the "shifting baselines" phenomenon. Changing conditions on the landscape combined with sometimes equivocal findings of monitoring creates the potential for shifts in expectations. Potential changes to desired outcomes should only be made with the goal of maintaining maximum practical ecosystem function and with full stakeholder participation.

An example of monitoring and adaptive management is the program of environmental flow releases from the Wolwedans Dam to the Great Brak Estuary in South Africa. Results of 30 years of monitoring were used to refine environmental flow releases and improve the effectiveness of artificial mouth breaching practiced as mitigation for flow reduction. This adaptive management process was driven by a complex stakeholder coalition involving scientists, government and local citizens [126]. Ongoing research and monitoring changed management practice within a 10-year review cycle [32]. This resulted in the efficient use of a limited historical environmental flow allocation in a water stressed catchment. This case study also shows how management objectives were continuously adjusted to accommodate escalating competition for water resources, not always to the benefit of the ecological function of the estuary. More recently management objectives have been legislated at a national level to ensure higher levels of management compliance in an effort to halt ongoing estuary degradation.

Implementation of the environmental flow framework shown in Figure 1 will require development of new assessment tools or modification of existing tools. Numerous monitoring and assessment protocols, interpretive frameworks, and indices have been developed globally. However, many of these may need to be adapted for TCEs which are often more dynamic over annual time scales. The effects of this dynamism were illustrated by Clark and O'Conner [17] who demonstrated heterogeneity within and between estuaries driven by variable periods of marsh inundation associated with mouth opening and closing (Figure 5). This study shows the importance of continuous and sustained monitoring. Furthermore, typical assessment indices, such as measures of diversity, richness, abundance, and composition need to be adjusted to reflect smaller size, inherently lower diversity and temporally dynamic conditions of TCEs. Revised indices and associated thresholds need to be recalibrated relative to appropriate and relevant reference sites. Assessment tools may be lacking for certain processes or characteristics of TCEs, such as tools to evaluate mouth dynamics and social and cultural issues associated with these systems. For example, small estuaries, with relatively low inflows along wave dominated and/or microtidal coastlines are often less resilient to anthropogenic pressures [24]. Temporarily closed estuaries are highly sensitive to shifts in mouth opening processes, changing water levels and declining water quality; this necessitates the development of new assessment tools $[15,18,41]$. Because small estuaries often exist in interconnected networks, new assessment tools should also be developed that can evaluate ecosystem functions across clusters or metapopulations of estuaries where processes and habitats may be coupled. These new indicators should also target parameters sensitive to changes in freshwater inflow. For example, Steichen et al. [127], proposed using fish as indicators of freshwater inflow by focusing on associated abiotic stressors such as nutrient load, salinity and temperature, which can be related to specific events in the hydrograph to include certain aspects of flow regime [128], as well as hydrologic alteration [44]. 


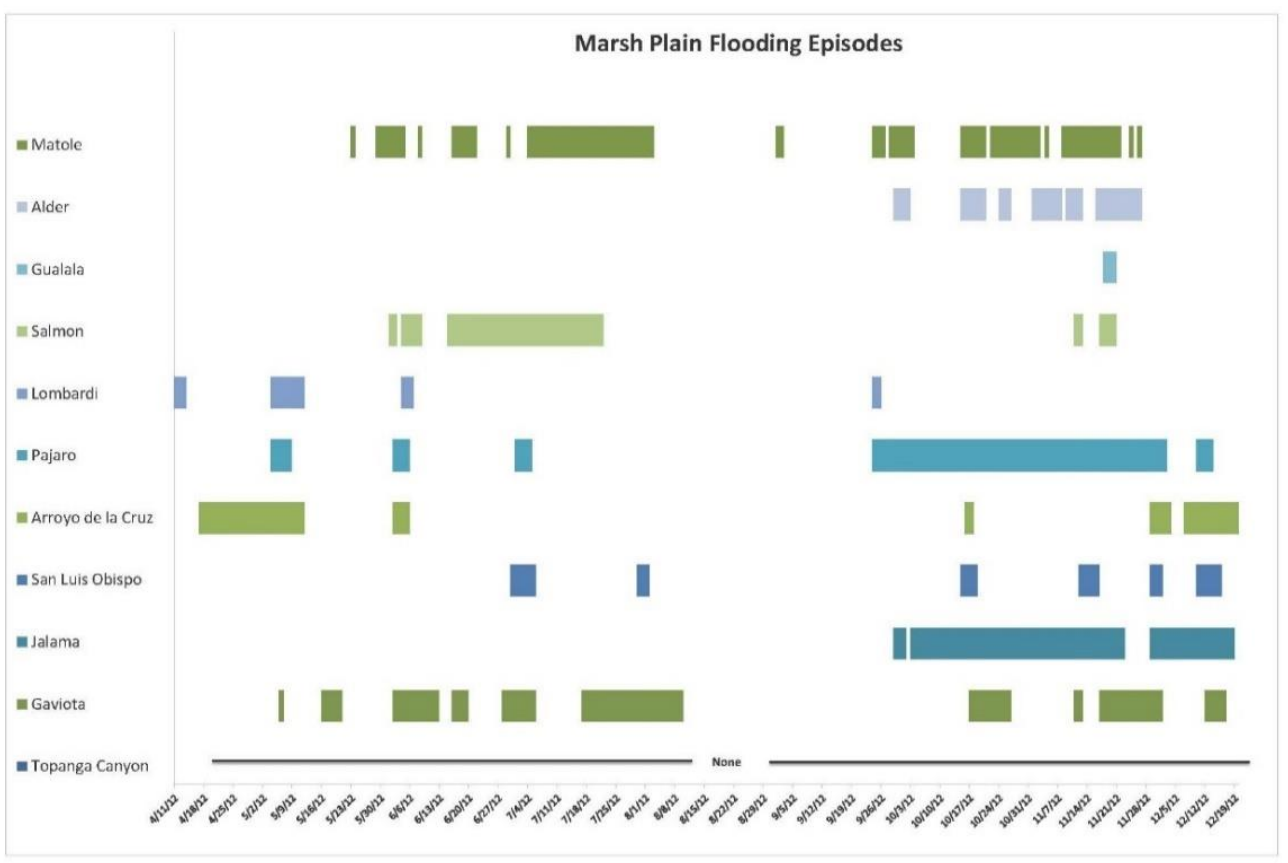

Figure 5. Patterns of marsh plain inundation associated with mouth state of intermittent estuaries in California. Y-axis lists individual estuaries monitored and shaded bars indicate period of time when the marsh plain was flooded due to mouth closure. From [17], reprinted with permission.

Ultimately, there is a need to link environmental flow monitoring and assessment with other watershed and coastal monitoring programs that can help provide insight into how hydrologic alteration interacts with other stressors, such as fishing, grazing, riparian development, aquaculture and/or invasive species that may exacerbate pressure that can lead to a concomitant decline in condition, resulting in the need to adjust environmental flow allocations to help account for the effect of multiple stressors. In California, this strategy is being testing by coupling condition assessment tools with a causal assessment framework, such as the one developed by the USEPA Causal Analysis/Diagnosis Decision Information System (CADDIS; https: / / www.epa.gov / caddis (accessed on 28 August 2020), [129]). Such a framework can be applied to TCEs to provide relatively rapid assessment of condition in a manner that can accommodate varying amounts of data availability. Condition can then be related to hydrologic change via relationships in community composition, indicator taxa, or other diagnostic measures. This would provide the ability to not only evaluate effects because of hydrologic change, but also monitor the effectiveness of management actions.

Adaptive management of environmental flows requires long-term monitoring data, such as continuous stream flow, water level recordings, mouth observations, longitudinal and vertical salinity distributions, and monitoring of nutrient concentrations and selected biotic components [15]. Long-term datasets are needed to capture variability and responses to events like droughts and large floods. These data sets are often absent because of limited human and financial resources but are especially important in highly dynamic TCEs to allow differentiating of changing functions from natural variability (i.e., signal to noise). Emerging threats to TCEs can cumulatively increase the sensitivity of the system because of changes in freshwater inflow. Only with long term time series data we can begin to understand historical patterns and implications of future conditions [84].

Sustained long-term monitoring is especially important to track the potential effects of accelerated climate change. The ability to predict the response of estuaries to climate change and to plan mitigation and adaptation strategies is hindered by a lack of good prediction tools and the lack of understanding of many of the effects of climate variability on the physical, chemical and biological characteristics $[130,131]$. Methods and tools are needed to assess the impacts of climate forcing on watershed and ocean forcing processes at regional scales to ensure that there is up take of such consideration in environmental 
flows studies. Protocols for the determination of environmental flows should also have these embedded as a standard application.

Monitoring should be coupled with a structured data management program. Data management provides the conduit to transform monitoring data to information that can be used to support management decisions. Although it is a critical element, data management is often underfunded and underdeveloped. As a result, information is often fragmented, difficult to coalesce, and/or largely inaccessible. Advances in software, open-source analytical tools, web services, and cloud storage have improved accessibility and may lower overall costs of data management, especially when data is leveraged to support sciencebased decision making. Allocation of staff and funding for ongoing data management should be prioritized as a critical element of environmental flow programs.

Development of monitoring, assessment and adaptive management strategies for environmental flow requirements in estuaries can be supported by the following research objectives:

- Identify ecological indicators that are sensitive to changing inflow requirements in TCEs;

- Adapt existing estuary monitoring tools to provide a consistent framework for evaluating the efficacy of ecological flow management in TCEs;

- Develop an approach for discerning functional shifts because of changing inflows from natural fluctuations;

- Couple monitoring with assessment of other stressors in an integrated conditioncausal assessment strategy;

- Develop mechanisms for sustained long-term monitoring and data dissemination.

\section{Conclusions and Recommendations}

Temporarily closed estuaries are globally ubiquitous, but highly threatened by watershed development, competition for freshwater resources, and climate change. Advancing the science and application of environmental flows is a critical step in protecting and managing these resources, but will require broadscale cooperation, coordination and commitment to address the following research priorities:

1. Agree on a consistent typology and classification to better account for variability in responses to hydrologic alteration.

(a) Directly relate estuary types/classes to susceptibility of changing inflow patterns including aligning with hydrologic regimes with ecological response across different points of the annual and interannual hydrograph.

(b) Include the role of groundwater discharge in the function of certain estuary types.

(c) Use the classification system to directly relate physical drivers to biological response variables and identify key knowledge gaps in the physical biological linkages.

(d) Identify flow management measures that may be most important to different estuary classes.

2. Expand our understanding of how changes in freshwater inflows will interact with changes in ocean forcing, and how will this influence decisions about setting environmental flow requirements:

(a) Downscale outputs of global climate models and embed in standard hydrological models, including the impacts of higher temperatures and increase evaporation. Results needs to be placed-based, with the calculation of key flow indicators automated.

(b) Conduct integrative research on synergistic effects of a changing climate. What would happen if freshwater flow is reduced, but sea level increases?

(c) Develop sediment budgets under current and future conditions and assess changes in sediment processes because of both ocean and watershed forc- 
ing at both local and regional scales to better understand effects on estuary morphology and resilience to climate change.

(d) Improve understanding of the role of extreme events (floods, coastal storm and storm surges) and decadal oscillations on estuarine processes and diversity, and how these events will be affected by climate change.

(e) Improve efficiency of models to capture both extreme and low intensity (high frequency) runoff events and dynamically couple these hydrologic patterns with changes in abiotic processes and biotic responses over long time scales.

(f) Improve remote sensing technologies and methods relevant to estuarine hydrographic and hydrologic data collection and data integration into numerical modeling processes.

3. Improve methods to assess ecosystem functions of TCEs and develop causal assessment tools to better elucidate responses to hydrologic alteration along with other stressors.

(a) Maintain long-term assessments to measure the health of rooted macrophytes, e.g., salt marsh/mangrove/macrophytes cover as measures of habitat and shoreline stabilization functions as well as directly measuring the impact of a stressor on those functions.

(b) Develop causal assessments tools that can provide information on the probable cause of an altered system and have the potential to determine what component of the flow regime is influencing an ecological function, e.g., the magnitude, or the timing of high flows.

(c) Establish relationships between salinity, turbidity, temperature, and nutrients and health and vigor of plant and animal communities through long-term monitoring of multiple types of TCEs.

(d) Improve tools that directly measure function, e.g., rates of primary productivity, as a component of the functional equivalency approach [92]. Establish meaningful thresholds to determine the difference between healthy and unhealthy systems.

(e) Develop tools to better evaluate cumulative and interacting effects on functions. For example, increasing inflows in a system may increase nutrient flushing and oxygen exchange, but may potentially have detrimental consequences involving reduced nutrient cycling and primary production on other aspects of the system [132].

4. Develop approaches that can help produce agreed upon expectations and quantifiable desired outcomes through an inclusive stakeholder process:

(a) Improve ways to identify and quantify trade-offs between competing values in the establishment of the desired conditions and end points. Develop a mechanism for sharing experiences and approaches globally on resolved tradeoffs and potential conflicts in endpoints.

(b) Develop tools and approaches to better incorporate cultural, social, and indigenous values into environmental flow assessments.

(c) Develop methods for identifying multiple reference points to create a trajectory of recovery from past to present to desired future condition, considering multiple domains including morphological, ecological and social, and incorporating the differences between trajectories of degradation and trajectories of recovery.

(d) Incorporate paleoecology and historical ecology to identify historical ecological states and processes and to establish reference conditions.

(e) Improve methods for incorporating climate change effects into decisions about desired outcomes. This should include consideration of how climate change effects the ability to achieve desired end points, including the effects on freshwater inflows, marine forcing, temperature, morphology, and ecological processes. 
Improve ability to understand connections between clusters or networks of TCEs and how changing flow conditions influence regional connectivity and function.

5. Develop monitoring, assessment and adaptive management strategies for environmental flow requirements in estuaries that can inform ongoing management and improve performance of models and other assessment tools:

(a) Identify ecological indicators that are sensitive to changing inflow requirements in TCEs.

(b) Adapt existing estuary monitoring tools to provide a consistent framework for evaluating the efficacy of ecological flow management in TCEs.

(c) Develop an approach for discerning functional shifts because of changing inflows from natural fluctuations.

(d) Couple monitoring with assessment of other stressors in an integrated conditioncausal assessment strategy.

(e) Develop mechanisms for sustained long-term monitoring and data dissemination.

Research needs should be prioritized based on the needs and constraints of individual situations. For example, needs may vary based on data availability, predominant stressors, or social issues. We have rated the above research priorities based on four factors relevant to decisions of resource or effort allocation (Table 2). Based on discussions at the 2019 Coastal and Estuarine Research Federation Annual meeting special session, we have identified five research needs that we believe would have the most universal impact on advancing the management of environmental flows in TCEs.

Consideration of environmental flows in an Integrated Water Resources Management (IWRM) framework has the potential to unify strategies to address both watershed and ocean derived hydrologic change [133,134]. IWRM requires the coordinated development and management of water and land resources; to maximize the resultant economic and social benefits in an equitable manner without compromising the sustainability of aquatic ecosystems in a watershed. IWRM results in improved water use, and supports economic and social objectives, while sustaining environmental ecosystems [135]. IWRM relies on a multidisciplinary, socio-ecological systems approach which integrates elements such as land and water issues, freshwater and coastal zones, water quantity and quality, differing upstream and downstream interests, and surface water and groundwater interactions. IWRM also requires trade-offs between alternative economic, social and environmental objectives, and between existing and future demands, such as those an uncertain climate change may impose on future water resource delivery and use [136].

Using an IWRM approach can support environmental flow assessments by providing a way to integrate potential effects on water quantity and quality with potential habitat changes. This implies that before embarking on an IWRM process a 'status quo' assessment is needed of all pressures on, and uses of estuaries in a water management area or watershed, as reflected in the present-but also those processes representative of a changing climate, to ensure an equitable and sustainable spread of benefits. IWRM recognizes that hydrology it is not the only factor that contributes to ecosystem change. It is also important to have a sound understanding of other global change pressures such as pollution, living resource exploitation, destruction of habitat and biological invasions [86]. Consideration of multiple vectors of change in the context of an uncertain climate future is rarely attempted. This should include assessing the impact of flow reduction, a deterioration in water quality and a climate change induced increase in temperature and tidal penetration. While it is near impossible to predict multi-vector ecosystems-level responses at a high level of confidence, demonstration of such methods is nevertheless urgently needed to progress in the context of IWRM and should be a high priority for research 
Table 2. Relative prioritization of identified research needs. Large black circles indicate relatively high ease of achieving, data availability, ability to accomplish in a short time frame, and high management impact. Small grey circles indicate relatively low levels for the same criteria. Red bolded text indicate highest priority needs for informing environmental flow management in TCEs.

Data Gaps and Research Needs

\begin{tabular}{|c|c|c|}
\hline 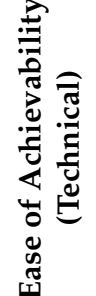 & 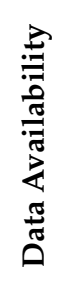 & 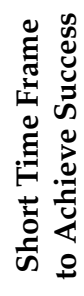 \\
\hline
\end{tabular}

\begin{tabular}{|c|c|c|c|c|}
\hline \multicolumn{5}{|l|}{ 1. Consistent typology/classification sensitive to hydrologic alteration } \\
\hline Relate exiting estuary classes to inflow patterns & $\bullet$ & - & $\bullet$ & $\bullet$ \\
\hline Include groundwater discharge into typology & - & - & - & - \\
\hline Use the classification to relate physical drivers to biological response & - & - & - & $\bullet$ \\
\hline Relate flow management measures to different estuary classes & • & • & • & $\bullet$ \\
\hline \multicolumn{5}{|c|}{ 2. Understand interaction between changes in freshwater inflows and ocean forcing } \\
\hline Embed downscaling of Global Climate models into hydrologic analysis & $\cdot$ & 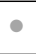 & $\cdot$ & $\bullet$ \\
\hline Integrate effect of reduced freshwater flow inflow and sea level rise & - & - & - & $\bullet$ \\
\hline Assess changes in sediment processes and budgets & $\bullet$ & $\bullet$ & - & • \\
\hline Role of extreme events and decadal oscillations & $\bullet$ & $\bullet$ & - & $\bullet$ \\
\hline Model various scale events over long time periods & - & $\cdot$ & - & $\bullet$ \\
\hline Remote sensing for data collection and input to numerical models & - & $\bullet$ & • & $\bullet$ \\
\hline \multicolumn{5}{|l|}{ 3. Methods to assess ecosystem functions and causal assessment tools } \\
\hline Long-term assessments of rooted macrophytes condition and stress & $\bullet$ & - & - & $\bullet$ \\
\hline Develop flow-based causal assessments tools & • & $\bullet$ & - & • \\
\hline Assess effects of salinity, turbidity, temperature, and nutrients & $\bullet$ & $\bullet$ & - & $\bullet$ \\
\hline Improve tools that measure function and establish health thresholds & - & $\bullet$ & - & $\bullet$ \\
\hline Cumulative Assessment tools of synergistic and antigenic effects & - & - & - & - \\
\hline \multicolumn{5}{|c|}{ 4. Approaches to produce agreed upon expectations and quantifiable desired outcomes } \\
\hline Trade-off methods for determining desired conditions/end points & $\bullet$ & $\bullet$ & $\bullet$ & $\bullet$ \\
\hline Approaches to incorporate cultural, social, and indigenous values & $\bullet$ & - & • & $\bullet$ \\
\hline Create recovery trajectories based on flow management & $\bullet$ & $\bullet$ & - & $\bullet$ \\
\hline Incorporate paleoecology and historical ecology for reference conditions & $\bullet$ & - & - & • \\
\hline Consider climate change into ability to achieve desired end points & - & $\bullet$ & - & $\bullet$ \\
\hline Role of regional connectivity between clusters/networks of TCEs & - & - & - & - \\
\hline \multicolumn{5}{|l|}{ 5. Monitoring, assessment, and adaptive management strategies } \\
\hline Identify ecological indicators sensitive to flow requirements in TCEs & $\bullet$ & $\bullet$ & $\bullet$ & $\bullet$ \\
\hline Consistent monitoring tools for evaluating ecological flow effects & $\bullet$ & $\bullet$ & - & $\bullet$ \\
\hline Discern role of natural fluctuations on functional shifts & - & $\bullet$ & - & $\bullet$ \\
\hline Monitor stressors in an integrated condition-causal assessment strategy & - & - & - & $\bullet$ \\
\hline Mechanisms for sustained long-term monitoring and data dissemination & $\bullet$ & - & • & $\bullet$ \\
\hline
\end{tabular}


Beyond this research agenda, implementing environmental flows for estuaries typically requires legislative or policy actions that enable technical solutions to be adopted. Managing environmental flows has the potential to accomplish objectives across numerous other programs and policies, such as habitat restoration, sensitive species protection (e.g., red list species), water quality programs, climate change adaptation and water resources planning. Environmental flow policies could occur either through new legislation or through incorporation of environmental flow considerations into existing policies. The former would have the advantage of allowing for design of a cohesive and comprehensive program around meeting environmental flow objectives, but would likely be more difficult to enact because of political obstacles to new policy development. In contrast, incorporation of environmental flow considerations into existing polices would be less specific, but likely easier to enact (i.e., lower barriers to development) — either way, policy drivers are key to advance the implementation of environmental flows. An informed research agenda anchored through global collaboration can serve as the foundation for any future policy proposals under consideration and can ultimately lead to more effective protection of these resources globally.

Author Contributions: Conceptualization, E.D.S., E.M.G., J.B.A., K.I., L.V.N.; investigation, E.D.S., E.M.G., J.B.A., K.I., L.V.N.; writing—original draft preparation, E.D.S., E.M.G., J.B.A., K.I., L.V.N.; writing - review and editing, E.D.S., E.M.G., J.B.A., K.I., L.V.N. All authors have read and agreed to the published version of the manuscript.

Funding: E.M.G. was funded through FWWA2103. The DSI/NRF Research Chair in Shallow Water Ecosystems (UID 84375) supported J.B.A. The South African Council for Scientific and Industrial Research (through its DST Parliamentary Grant) supported L.V.N.

Institutional Review Board Statement: Not applicable.

Informed Consent Statement: Not applicable.

Data Availability Statement: Not applicable.

Acknowledgments: We thank the many researchers and managers whose dedication to understanding temporary closed estuaries informed this work. Many of the concepts and ideas originated during a special session at the 2019 Coastal and Estuarine Research Federation Conference in Mobile, AL, USA. We thank all the participants for their input and challenging ideas. We thank Paul Montagna and Anne Giblin for their review and suggestions on the draft manuscript. Figure 3 is modified from a base figure provided courtesy of the California State Coastal Conservancy and San Francisco Estuary Institute. Figure 5 is reprinted with permission from Estuarine, Coastal and Shelf Science.

Conflicts of Interest: The authors declare no conflict of interest.

\section{References}

1. Arthington, A.H.; Bhaduri, A.; Bunn, S.E.; Jackson, S.E.; Tharme, R.E.; Tickner, D.; Young, B.; Acreman, M.; Baker, N.; Capon, S.; et al. The Brisbane Declaration and Global Action Agenda on Environmental Flows. Front. Environ. Sci. 2018, 6, 45. [CrossRef]

2. Arthington, A.H.; Kennen, J.G.; Stein, E.D.; Webb, J.A. Recent advances in environmental flows science and water managementInnovation in the Anthropocene. Freshw. Biol. 2018, 63, 1022-1034. [CrossRef]

3. Zharikov, Y.; Skilleter, G.A.; Loneragan, N.R.; Taranto, T.; Cameron, B.E. Mapping and characterizing subtropical estuarine landscapes using aerial photography and GIS for potential application in wildlife conservation and management. Biol. Conserv. 2005, 125, 87-100. [CrossRef]

4. Lloyd, L.N.; Anderson, B.G.; Cooling, M.; Gippel, C.J.; Pope, A.J.; Sherwood, J.E. Estuary Environmental Flows Assessment Methodology: Final Specification Report; Report to Corangamite CMA; Lloyd Environmental Pty Ltd.: Colac, Australia, 2009.

5. Behrens, D.K.; Brennan, M.; Battalio, P.E. A quantified conceptual model of inlet morphology and associated lagoon hydrology. Shore Beach 2015, 83, 33-42.

6. McSweeney, S.; Kennedy, D.; Rutherfurd, I. A geomorphic classification of intermittently open/closed estuaries (IOCE) derived from estuaries in Victoria, Australia. Prog. Phys. Geogr. Earth Environ. 2017, 41, 421-449. [CrossRef]

7. Costanza, R.; D'arge, R.; De Groot, R.; Farber, S.; Grasso, M.; Hannon, B.; Limburg, K.; Naeem, S.; O'Niell, R.V.; Paruelo, J.; et al. The value of the world's ecosystem services and natural capital. Nature 1997, 387, 253-259. [CrossRef]

8. Adams, J.B. A review of methods and frameworks used to determine the environmental water requirements of estuaries. Hydrol. Sci. J. 2014, 59, 451-465. [CrossRef] 
9. Kimmerer, W.J. Physical, biological, and management responses to variable freshwater inflow into the San Francisco Estuary. Estuaries 2000, 25, 1275-1290. [CrossRef]

10. Powell, G.L.; Matsumoto, J.; Brock, D.A. Methods for determining minimum freshwater inflow needs of Texas bays and estuaries. Estuaries 2002, 25, 1262-1274. [CrossRef]

11. Jha, R.; Sharma, K.D.; Singh, V.P. Critical appraisal of methods for the assessment of environmental flows and their application in two river systems of India. KSCE J. Civ. Eng. 2008, 12, 213-219. [CrossRef]

12. Sun, T.; Xu, J.; Yang, Z.F. Environmental flow assessments in estuaries based on an integrated multi-objective method. Hydrol. Earth Syst. Sci. 2013, 17, 751-760. [CrossRef]

13. Ryan, D.A.; Heap, A.D.; Radke, L.; Heggie, D.T. Conceptual Models of Australia's Estuaries and Coastal Waterways: Applications for Coastal Resource Management; Geoscience Australia: Canberra, Australia, 2003; 136p.

14. Gee, E. An Approach to Environmental Flows for Estuaries. In Proceedings of the 12th ISE Conference, Tokyo, Japan, 19-24 August 2018.

15. Adams, J.B.; Van Niekerk, L. Ten Principles to Determine Environmental Flow Requirements for Temporarily Closed Estuaries. Water 2020, 12, 1944. [CrossRef]

16. Saintilan, N.; Rogers, K.; Toms, C.; Stein, E.D.; Jacobs, D. Intermittent Estuaries: Linking Hydro-geomorphic Context to Climate Change Resilience. J. Coast. Res. 2016, 75, 133-137. [CrossRef]

17. Clark, R.; O'Connor, K. A systematic survey of bar-built estuaries along the California coast. Estuar. Coast. Shelf Sci. 2019, 226, 106285. [CrossRef]

18. Van Niekerk, L.; Taljaard, S.; Adams, J.B.; Lamberth, S.J.; Huizinga, P.; Turpie, J.K.; Wooldridge, T.H. An environmental flow determination method for integrating multiple-scale ecohydrological and complex ecosystem processes in estuaries. Sci. Total. Environ. 2019, 656, 482-494. [CrossRef]

19. Whitfield, A.; Elliott, M. Ecosystem and Biotic Classifications of Estuaries and Coasts. Treatise Estuar. Coast. Sci. 2011, 1, 99-124. [CrossRef]

20. Allen, J.R.L. An Introduction to Estuarine Lithosomes and their Controls. Sedimentol. Rev. 2009, 123-138. [CrossRef]

21. Davies, J.L. A Morphogenetic Approach to World Shorelines. Z. Geomorphol. 1964, 8, 127. [CrossRef]

22. Hayes, M.O. Morphology of sand accumulation in estuaries: An introduction to the symposium. Geol. Eng. 1975, 2, 3-22. [CrossRef]

23. Tweedley, J.; Warwick, R.; Potter, I. The Contrasting Ecology of Temperate Macrotidal and Microtidal Estuaries. In Oceanography and Marine Biology: An Annual Review; CRC Press: Boca Raton, FL, USA, 2016; pp. 73-172.

24. Warwick, R.M.; Tweedley, J.R.; Potter, I.C. Microtidal estuaries warrant special management measures that recognise their critical vulnerability to pollution and climate change. Mar. Pollut. Bull. 2018, 135, 41-46. [CrossRef]

25. Keith, D.A.; Ferrer, J.R.; Nicholson, E.; Bishop, M.J.; Polidoro, B.A.; Llodra, E.R.; Tozer, M.G.; Nel, J.L.; Nally, R.M.; Gregr, E.J.; et al. The IUCN Global Ecosystem Typology v1.01: Descriptive profiles for Biomes and Ecosystem Functional Groups; IUCN: New York, NY, USA, 2020.

26. Engle, V.D.; Kurtz, J.C.; Smith, L.M.; Chancy, C.; Bourgeois, P. A Classification of U.S. Estuaries Based on Physical and Hydrologic Attributes. Environ. Monit. Assess. 2007, 129, 397-412. [CrossRef]

27. Edgar, G.J.; Barrett, N.S.; Graddon, D.J.; Last, P.R. The conservation significance of estuaries: A classification of Tasmanian estuaries using ecological, physical and demographic attributes as a case study. Biol. Conserv. 2000, 92, 383-397. [CrossRef]

28. Hume, T.M.; Snelder, T.; Weatherhead, M.; Liefting, R. A controlling factor approach to estuary classification. Ocean Coast. Manag. 2007, 50, 905-929. [CrossRef]

29. Rich, A.; Keller, E.A. Watershed Controls on the Geomorphology of Small Coastal Lagoons in an Active Tectonic Environment. Chesap. Sci. 2011, 35, 183-189. [CrossRef]

30. Roy, P.; Williams, R.; Jones, A.; Yassini, I.; Gibbs, P.; Coates, B.; West, R.; Scanes, P.; Hudson, J.; Nichol, S. Structure and Function of South-east Australian Estuaries. Estuar. Coast. Shelf Sci. 2001, 53, 351-384. [CrossRef]

31. Jacobs, D.K.; Stein, E.D.; Longcore, T. Classification of California Estuaries Based on Natural Closure Patterns: Templates for Restoration and Management Management. South. Calif. Coast. Water Res. Proj. Tech. Rep. 2011, 619, 1-50.

32. Van Niekerk, L.; Adams, J.; James, N.; Lamberth, S.; Mackay, C.; Turpie, J.; Rajkaran, A.; Weerts, S.; Whitfield, A. An Estuary Ecosystem Classification that encompasses biogeography and a high diversity of types in support of protection and management. Afr. J. Aquat. Sci. 2020, 45, 199-216. [CrossRef]

33. Boyd, R.; Dalrymple, R.; Zaitlin, B.; Boyd, R.; Dalrymple, R.; Zaitlin, B. Classification of clastic coastal depositional environments. Sediment. Geol. 1992, 80, 139-150. [CrossRef]

34. Dalrymple, R.W.; Zaitlin, B.A.; Boyd, R. A conceptual model of estuarine sedimentation. J. Sediment. Petrol. 1992, 62, 1130-1146. [CrossRef]

35. Kench, P.S. Geomorphology of Australian estuaries: Review and prospect. Austral Ecol. 1999, 24, 367-380. [CrossRef]

36. Heggie, D.T.; Skyring, G.W.; Berelson, W.E.; Longmore, A.R.; Nicholson, G.J. Sediment-water interaction in Australian coastal environments: Implications for water and sediment quality. AGSO J. Aust. Geol. Geophys. 1999, 17, $159-173$.

37. Heggie, D.T.; Skyring, G.W. Flushing of Australian estuaries, coastal lakes and embayments: An overview with biochemical commentary. AGSO J. Aust. Geol. Geophys. 1999, 17, 211-225. 
38. Largier, J.L.; Slinger, J.H.; Taljaards, S. The stratified hydrodynamics of the Palmiet-A prototype bar-built estuary. In Dynamics and Exchanges in Estuaries and Coastal Seas; Springer: New York, NY, USA, 1991.

39. Goodwin, P. Predicting the stability of tidal inlets for wetland and estuary management. J. Coast. Res. 1996, $23,83-101$.

40. Behrens, D.K.; Bombardelli, F.A.; Largier, J.L.; Twohy, E. Episodic closure of the tidal inlet at the mouth of the Russian River-A small bar-built estuary in California. Geomorphology 2013, 189, 66-80. [CrossRef]

41. Van Niekerk, L.; Adams, J.B.; Allen, D.; Taljaard, S.; Weerts, S.; Louw, D.; Talanda, C.; Van Rooyen, P. Assessing and Planning Future Estuarine Resource Use: A Scenario-Based Regional Scale Freshwater Allocation Approach. Sci. Total Environ. 2019, 657, 1000-1013. [CrossRef] [PubMed]

42. Poff, N.L.; Ward, J.V. Implications of Streamflow Variability and Predictability for Lotic Community Structure: A Regional Analysis of Streamflow Patterns. Can. J. Fish. Aquat. Sci. 1989, 46, 1805-1818. [CrossRef]

43. Poff, N.L.; Allan, J.D.; Bain, M.B.; Karr, J.R.; Prestegaard, K.L.; Richter, B.D.; Sparks, R.E.; Stromberg, J.C. The natural flow regime: A paradigm for river conservation and restoration. BioScience 1997, 47, 769-784. [CrossRef]

44. Olden, J.D.; Poff, N.L. Redundancy and the choice of hydrologic indices for characterizing streamflow regimes. River Res. Appl. 2003, 19, 101-121. [CrossRef]

45. Beck, J.S.; Theron, A.T.; Kemp, A.; Huizinga, P.; Basson, G.R. Hydraulics of Estuarine Sediment Dynamics in South Africa—Implications for Estuarine Reserve Determination and the Development of Management Guidelines; WRC Report No 1257/1/04; Water Research Commission: Pretoria, South Africa, 2004.

46. IPCC. Climate Change 2014: Synthesis Report. Contribution of Working Groups I, II, and III to the Fifth Assessment Report of the In-tergovernmental Panel on Climate Change; IPCC: Geneva, Switzerland, 2014; p. 151.

47. Attrill, M.J. A testable linear model for diversity trends in estuaries. J. Anim. Ecol. 2002, 71, 262-269. [CrossRef]

48. Ranasinghe, R.; Pattiaratchi, C. The seasonal closure of tidal inlets: Wilson Inlet-A case study. Coast. Eng. 1999, 37, 37-56. [CrossRef]

49. Kearney, M.S.; Grace, R.E.; Stevenson, J.C. Marsh Loss in Nanticoke Estuary, Chesapeake Bay. Geogr. Rev. 1988, 78, 205. [CrossRef]

50. Raw, J.L.; Riddin, T.; Lehman, T.W.K.; Bornman, T.G.; Adams, J.B. Salt marsh surface elevation and responses to future sea-level rise in the Knysna Estuary. Afr. J. Aquat. Sci. 2020, 45, 49-64. [CrossRef]

51. Beckett, L.H.; Baldwin, A.H.; Kearney, M.S. Tidal marshes across a chesapeake bay subestuary are not keeping up with sea-level rise. PLoS ONE 2016, 11, e0159753. [CrossRef]

52. Komar, P.D.; Allan, J.C. Increasing Hurricane-Generated Wave Heights along the U.S. East Coast and Their Climate Controls. J. Coast. Res. 2008, 242, 479-488. [CrossRef]

53. Ruggiero, P.; Komar, P.D.; Allan, J.C. Increasing wave heights and extreme value projections: The wave climate of the U.S. Pacific Northwest. Coast. Eng. 2010, 57, 539-552. [CrossRef]

54. Duong, T.M.; Ranasinghe, R.; Walstra, D.; Roelvink, D. Assessing climate change impacts on the stability of small tidal inlet systems: Why and how? Earth Sci. Rev. 2016, 154, 369-380. [CrossRef]

55. Duong, T.M.; Ranasinghe, R.; Luijendijk, A.; Walstra, D.; Roelvink, D. Assessing climate change impacts on the stability of small tidal inlets: Part 1—Data poor environments. Mar. Geol. 2017, 390, 331-346. [CrossRef]

56. Francisco, A.S.; Netto, S.A. El Niño-Southern Oscillations and Pacific Decadal Oscillation as Drivers of the Decadal Dynamics of Benthic Macrofauna in Two Subtropical Estuaries (Southern Brazil). Ecosystems 2020, 23, 1380-1394. [CrossRef]

57. Harvey, M.E.; Giddings, S.N.; Stein, E.D.; Crooks, J.A.; Whitcraft, C.; Gallien, T.; Largier, J.L.; Tiefenthaler, L.; Meltzer, H.; Pawlak, G.; et al. Effects of Elevated Sea Levels and Waves on Southern California Estuaries During the 2015-2016 El Niño. Chesap. Sci. 2020, 43, 256-271. [CrossRef]

58. Rose, T.H.; Tweedley, J.R.; Warwick, R.M.; Potter, I.C. Influences of microtidal regime and eutrophication on estuarine zooplankton. Estuar. Coast. Shelf Sci. 2020, 238, 106689. [CrossRef]

59. Trenberth, K. Changes in precipitation with climate change. Clim. Res. 2011, 47, 123-138. [CrossRef]

60. Giorgi, F.; Lionello, P. Climate change projections for the Mediterranean region. Glob. Planet. Chang. 2008, 63, 90-104. [CrossRef]

61. Kennish, M.J. Estuarine Research, Monitoring, and Resource Protection; CRC Marine Science; CRC Press: Boca Raton, FL, USA, 2003. Available online: https:/ / books.google.com/books?id=UdICWCidu9oC (accessed on 29 June 2020).

62. Fisher, T.R.; Harding, L.W.; Stanley, D.W.; Ward, L.G. Phytoplankton, nutrients, and turbidity in the Chesapeake, Delaware, and Hudson estuaries. Estuar. Coast. Shelf Sci. 1988, 27, 61-93. [CrossRef]

63. Harrison, T.D. Biogeography and Community Structure of Fishes in South African Estuaries. Ph.D. Thesis, Rhodes University, Grahamstown, South Africa, 2003.

64. Whitfield, A.K. Ichthyofaunal assemblages in estuaries: A South African case study. Rev. Fish Biol. Fish. 1999, 9, 151-186. [CrossRef]

65. James, N.C.; Cowley, P.D.; Whitfield, A.K.; Lamberth, S.J. Fish communities in temporarily open/closed estuaries from the warmand cool-temperate regions of South Africa: A review. Rev. Fish Biol. Fish. 2007, 17, 565-580. [CrossRef]

66. Lellis-Dibble, K.; McGlynn, K.E.; Bigford, T.E. Estuarine Fish and Shellfish Species in U.S. Commercial and Recreational Fisheries: Economic Value as an Incentive to Protect and Restore Estuarine Habitat; NOAA Tech. Memo. NMFS- F/SPO-90; U.S. Department Commerce: Washington, DC, USA, 2008.

67. Dekshenieks, M.M.; Hofmann, E.E.; Klinck, J.M.; Powell, E.N. Quantifying the effects of environmental change on an oyster population: A modeling study. Estuaries 2000, 23, 593. [CrossRef] 
68. Rice, M.A. Environmental Effects of Shellfish Aquaculture in the Northeast. NRAC Publication. 2008. Available online: http:/ / seagrant.uconn.edu/whatwedo/aquaculture/pdf/nrac105-environeff.pdf (accessed on 30 June 2020).

69. Costanza, R.; Pérez-Maqueo, O.; Martinez, M.L.; Sutton, P.; Anderson, S.J.; Mulder, K. The Value of Coastal Wetlands for Hurricane Protection. AMBIO 2008, 37, 241-248. [CrossRef]

70. Shepard, C.C.; Crain, C.M.; Beck, M.W. The Protective Role of Coastal Marshes: A Systematic Review and Meta-analysis. PLoS ONE 2011, 6, e27374. [CrossRef]

71. Barbier, E.B. Valuing Ecosystem Services for Coastal Wetland Protection and Restoration: Progress and Challenges. Resources 2013, 2, 213-230. [CrossRef]

72. Kirwan, M.L.; Temmerman, S.; Skeehan, M.L.K.E.E.; Guntenspergen, G.R.; Fagherazzi, S. Overestimation of marsh vulnerability to sea level rise. Nat. Clim. Chang. 2016, 6, 253-260. [CrossRef]

73. Chuwen, B.M.; Hoeksema, S.D.; Potter, I.C. Factors influencing the characteristics of the fish faunas in offshore, deeper waters of permanently-open, seasonally-open and normally-closed estuaries. Estuar. Coast. Shelf Sci. 2009, 81, 279-295. [CrossRef]

74. Riddin, T.; Adams, J. The effect of a storm surge event on the macrophytes of a temporarily open/closed estuary, South Africa. Estuar. Coast. Shelf Sci. 2010, 89, 119-123. [CrossRef]

75. Bennett, B.A. A mass mortality of fish associated with low salinity conditions in the bot river estuary. Trans. R. Soc. S. Afr. 1985, 45, 437-447. [CrossRef]

76. Huang, P.; Kilminster, K.; Larsen, S.; Hipsey, M.R. Assessing artificial oxygenation in a riverine salt-wedge estuary with a three-dimensional finite-volume model. Ecol. Eng. 2018, 118, 111-125. [CrossRef]

77. Cottingham, A.; Hesp, S.A.; Hall, N.G.; Hipsey, M.R.; Potter, I.C. Marked deleterious changes in the condition, growth and maturity schedules of Acanthopagrus butcheri (Sparidae) in an estuary reflect environmental degradation. Estuar. Coast. Shelf Sci. 2014, 149, 109-119. [CrossRef]

78. Douglas, G.B.; Hamilton, D.; Gerritse, R.G.; Adeney, J.A.; Coad, D. Sediment Geochemistry, Nutrient Fluxes and Water Quality in the Swan River Estuary, Western Australia; Davis, J.R., Ed.; Managing Algal Blooms: Outcomes from CSIRO's Multi-Divisional Blue-Green Algal Program; CSIRO Land and Water: Canberra, Australia, 1997; pp. 15-30.

79. Kurup, R.G.; Hamilton, D.P. Flushing of dense, hypoxic water from a cavity of the Swan River estuary, Western Australia. Estuaries 2002, 25, 908-915. [CrossRef]

80. Monbet, Y. Control of Phytoplankton Biomass in Estuaries: A Comparative Analysis of Microtidal and Macrotidal Estuaries. Estuaries 1992, 15, 563-571. [CrossRef]

81. Hallett, C.S.; Valesini, F.J.; Clarke, K.R.; Hoeksema, S.D. Effects of a harmful algal bloom on the community ecology, movements and spatial distributions of fishes in a microtidal estuary. Hydrobiologia 2015, 763, 267-284. [CrossRef]

82. Artigas, M.; Llebot, C.; Ross, O.; Neszi, N.; Rodellas, V.; Garcia-Orellana, J.; Masque, P.; Piera, J.; Estrada, M.; Berdalet, E. Understanding the spatio-temporal variability of phytoplankton biomass distribution in a microtidal Mediterranean estuary. Deep. Sea Res. Part II Top. Stud. Oceanogr. 2014, 101, 180-192. [CrossRef]

83. Dijkstra, Y.M.; Chant, R.J.; Reinfelder, J.R. Factors Controlling Seasonal Phytoplankton Dynamics in the Delaware River Estuary: An Idealized Model Study. Chesap. Sci. 2019, 42, 1839-1857. [CrossRef]

84. Cloern, J.E.; Foster, S.; Kleckner, A.E. Phytoplankton primary production in the world's estuarine-coastal ecosystems. Biogeosciences 2014, 11, 2477-2501. [CrossRef]

85. Cioffi, F.; Gallerano, F. Management strategies for the control of eutrophication processes in Fogliano lagoon (Italy): A long-term analysis using a mathematical model. Appl. Math. Model. 2001, 25, 385-426. [CrossRef]

86. Van Niekerk, L.; Taljaard, S.; Huizinga, P. An Evaluation of the Ecological Flow Requirements of South Africa's Estuaries from a Hydrodynamics Perspective; Water Research Commission: Rietfontein, South Africa, 2012.

87. Tamario, C.; Sunde, J.; Petersson, E.; Tibblin, P.; Forsman, A. Ecological and Evolutionary Consequences of Environmental Change and Management Actions for Migrating Fish. Front. Ecol. Evol. 2019, 7, 1-24. [CrossRef]

88. Lucas, L.V.; Thompson, J.K.; Brown, L.R. Why are diverse relationships observed between phytoplankton biomass and transport time? Limnol. Oceanogr. 2009, 54, 381-390. [CrossRef]

89. Ficke, A.D.; Myrick, C.A.; Hansen, L.J. Potential impacts of global climate change on freshwater fisheries. Rev. Fish Biol. Fish. 2007, 17, 581-613. [CrossRef]

90. Wooldridge, T.; Adams, J.; Fernandes, M. Biotic responses to extreme hypersalinity in an arid zone estuary, South Africa. S. Afr. J. Bot. 2016, 107, 160-169. [CrossRef]

91. Largier, J.; Hollibaugh, J.; Smith, S. Seasonally Hypersaline Estuaries in Mediterranean-climate Regions. Estuar. Coast. Shelf Sci. 1997, 45, 789-797. [CrossRef]

92. Fulford, R.; Russell, M.; Hagy, J.; Breitburg, D. Managing estuaries for ecosystem function. Glob. Ecol. Conserv. 2020, 21, e00892. [CrossRef]

93. Elliott, M.; Mander, L.; Mazik, K.; Simenstad, C.; Valesini, F.; Whitfield, A.; Wolanski, E. Ecoengineering with Ecohydrology: Successes and failures in estuarine restoration. Estuar. Coast. Shelf Sci. 2016, 176, 12-35. [CrossRef]

94. Pelletier, M.C.; Ebersole, J.; Mulvaney, K.; Rashleigh, B.; Gutierrez, M.N.; Chintala, M.; Kuhn, A.; Molina, M.; Bagley, M.; Lane, C. Resilience of aquatic systems: Review and management implications. Aquat. Sci. 2020, 82, 1-25. [CrossRef] 
95. Lloyd, L.N.; Anderson, B.G.; Cooling, M.; Gippel, C.J.; Pope, A.J.; Sherwood, J.E. Estuary Environmental Flows Assessment Methodology for Victoria; Report to the Department of Sustainability and Environment, Melbourne Water and Corangamite CMA; Lloyd Environmental Pty Ltd.: Colac, Australia, 2012.

96. Alber, M. A conceptual model of estuarine freshwater inflow management. Estuaries 2002, 25, 1246-1261. [CrossRef]

97. Stein, E.D.; Doughty, C.L.; Lowe, J.; Cooper, M.; Sloane, E.B.; Bram, D.L. Establishing Targets for Regional Coastal Wetland Restoration Planning Using Historical Ecology and Future Scenario Analysis: The Past, Present, Future Approach. Chesap. Sci. 2020, 43, 207-222. [CrossRef]

98. Duarte, C.M.; Borja, A.; Carstensen, J.; Elliott, M.; Krause-Jensen, D.; Marbà, N. Paradigms in the Recovery of Estuarine and Coastal Ecosystems. Chesap. Sci. 2013, 38, 1202-1212. [CrossRef]

99. Harris, J.; van Diggelen, R. Ecological Restoration as a Project for Global Society; van Andel, J., Aronson, J., Eds.; Restoration Ecology, Blackwell Science Publishers: Oxford, UK, 2006; pp. 3-15.

100. Choi, Y.D.; Temperton, V.M.; Allen, E.B.; Grootjans, A.P.; Halassy, M.; Hobbs, R.J.; Naeth, M.A.; Török, K. Ecological restoration for future sustainability in a changing environment. Écoscience 2008, 15, 53-64. [CrossRef]

101. Landscape South Australia, n.d. Available online: https://landscape.sa.gov.au/mr-rap/Subregions/Lower-Lakes-and-Coorong/ All-issues /1lc-23 (accessed on 9 July 2020).

102. Mosley, L.; Zammit, B.; Jolley, A.; Barnett, L. Acidification of lake water due to drought. J. Hydrol. 2014, 511, 484-493. [CrossRef]

103. Schallenberg, M.; Larned, S.; Hayward, S.; Arbuckle, C. Contrasting effects of managed opening regimes on water quality in two intermittently closed and open coastal lakes. Estuar. Coast. Shelf Sci. 2010, 86, 587-597. [CrossRef]

104. Scanes, E.; Scanes, P.R.; Ross, P.M. Climate change rapidly warms and acidifies Australian estuaries. Nat. Commun. 2020, $11,1-11$. [CrossRef]

105. Doughty, C.L.; Cavanaugh, K.C.; Ambrose, R.F.; Stein, E.D. Evaluating regional resiliency of coastal wetlands to sea level rise through hypsometry-based modeling. Glob. Chang. Biol. 2019, 25, 78-92. [CrossRef]

106. Collins, D.; Montgomery, K.; Zammit, C. Hydrological Projections for New Zealand Rivers under Climate Change I Ministry for the Environment (No. 2018193CH); Prepared for the Ministry for the Environment; NIWA: Christchurch, New Zealand, 2018.

107. Gillson, J. Freshwater Flow and Fisheries Production in Estuarine and Coastal Systems: Where a Drop of Rain Is Not Lost. Rev. Fish. Sci. 2011, 19, 168-186. [CrossRef]

108. Petitgas, P.; Rijnsdorp, A.D.; Dickey-Collas, M.; Engelhard, G.H.; Peck, M.A.; Pinnegar, J.K.; Drinkwater, K.; Huret, M.; Nash, R.D.M. Impacts of climate change on the complex life cycles of fish. Fish. Oceanogr. 2012, 22, 121-139. [CrossRef]

109. Berteaux, D.; De Blois, S.; Angers, J.-F.; Bonin, J.; Casajus, N.; Darveau, M.; Fournier, F.; Humphries, M.M.; McGill, B.; Larivée, J.; et al. The CC-bio project: Studying the effects of climate change on quebec biodiversity. Diversity 2010, 2, 1181-1204. [CrossRef]

110. Rudnick, D.; Beier, P.; Cushman, S.; Dieffenbach, F.; Epps, C.W.; Gerber, L.; Hartter, J.; Jenness, J.; Kintsch, J.; Merenlender, A.M.; et al. The Role of Landscape Connectivity in Planning and Implementing Conservationand Restoration 38 Priorities, 2012. Issues in Ecology; Report No. 16; Ecological Society of America: Washington, DC, USA, 2012.

111. Tipa, G.; Nelson, K. Environmental Flow Assessments: A Participatory Process Enabling Maori Cultural Values to Inform Flow Regime Setting. In Water, Cultural Diversity, and Global Environmental Change: Emerging Trends, Sustainable Futures; Johnston, B.R., Hiwasaki, L., Klaver, I.J., Ramos Castillo, A., Strang, V., Eds.; Springer: Dordrecht, The Netherlands, 2011 ; pp. $467-491$.

112. Tipa, G.; Harmsworth, G.; Williams, E.; Kitson, J.C. Integrating matauranga Maori into freshwater management, planning and decision-making. In Advances in New Zealand Freshwater Science; New Zealand Hydrologial Society, New Zealand Limnological Society: Wellington, New Zealand, 2016; pp. 613-638.

113. Horne, A.C.; O’Donnell, E.L.; Loch, A.J.; Adamson, D.C.; Hart, B.; Freebairn, J. Environmental water efficiency: Maximizing benefits and minimizing costs of environmental water use and management. Wiley Interdiscip. Rev. Water 2018, 5 , e1285. [CrossRef]

114. Brown, C.; Campher, D.; King, J. Status and trends in EFlows in southern Africa. Nat. Resour. Forum 2020, 44, 66-88. [CrossRef]

115. Brown, C.; King, J.; Van Niekerk, L.; Taljaard, S. Guidelines on Environmental Flows (EFlows) Assessments for the Western Indian Ocean Region; United Nations Environment Programme/Nairobi Convention Secretariat: Nairobi, Kenya, 2020.

116. Water Framework Directive (WFD). Directive 2000/60/EC of the European Parliament and of the Council of 23 October 2000 Establishing a Framework for Community Action in the Field of Water Policy; EU: Brussels, Belgium, 2000.

117. Acreman, M.C.; Ferguson, A.J.D. Environmental flows and the European Water Framework Directive. Freshw. Biol. 2010, 55, 32-48. [CrossRef]

118. MfE. 2020. Available online: https://www.mfe.govt.nz/publications/fresh-water/action-healthy-waterways-information-iwiand-maori (accessed on 9 July 2020).

119. Van Niekerk, L.; Adams, J.B.; Taljaard, S.; Huizinga, P.; Lamberth, S.J. Chapter 6. Advancing Mouth Management Practices in Groot Brak Estuary, South Africa. In Complex Coastal Systems-Transdisciplinary Learning on International Case Studies; Slinger, J.H., Taljaard, S., d'Hont, F., Eds.; Delft Academic Press: Delft, The Netherlands, 2020; pp. 89-104, ISBN 9789065624437.

120. Grantham, T.; Mount, J.; Stein, E.D.; Yarnell, S.M. Making the Most of Water for the Environment: A Functional Flows Approach for California's Rivers; Southern California Coastal Water Research Project Technical Report \#1142; Public Policy Institute of California: San Francisco, CA, USA, 2020. 
121. Hallett, C.S.; Hobday, A.J.; Tweedley, J.R.; Thompson, P.A.; McMahon, K.; Valesini, F.J. Observed and predicted impacts of climate change on the estuaries of south-western Australia, a Mediterranean climate region. Reg. Environ. Chang. 2018, 18, 1357-1373. [CrossRef]

122. Cilliers, G.; Adams, J. Development and implementation of a monitoring programme for South African estuaries. Water 2016, 42, 279. [CrossRef]

123. Horne, A.C.; Webb, J.A.; O’Donnell, E.; Arthington, A.H.; McClain, M.; Bond, N.; Acreman, M.; Hart, B.; Stewardson, M.J.; Richter, B.; et al. Research priorities to improve future environmental water outcomes. Front. Environ. Sci. 2017, 5, 89. [CrossRef]

124. Stankey, G.H.; Roger, N.C.; Bormann, B.T. Adaptive Management of Natural Resources: Theory, Concepts and Management Institutions; General Technical Report PNW-GTR-654; US Department of Agriculture, Forest Service, Pacific Northwest Research Station: Portland, OR, USA, 2005; p. 73.

125. Squires, V.R. Chapter 14: Concluding Thoughts on Ecological Restoration: Global Challenges, Social Aspects and Environmental Benefits. In Ecological Restoration; Squires, V.R., Ed.; Nova Science Publishers, Inc.: New York, NY, USA, 2016; ISBN 978-1-63484611-0.

126. Taljaard, S.; Slinger, J.H.; Morant, P.D.; Theron, A.K.; Van Niekerk, L.; Van Der Merwe, J. Implementing integrated coastal management in a sector-based governance system. Ocean Coast. Manag. 2012, 67, 39-53. [CrossRef]

127. Steichen, J.L.; Quigg, A. Fish species as indicators of freshwater inflow within a subtropical estuary in the Gulf of Mexico. Ecol. Indic. 2018, 85, 180-189. [CrossRef]

128. Quigg, A.; Steichen, J.; Guthrie, C.; Schoenbaechler, C. Defining Bioindicators for Freshwater Inflow Needs Studies; Vol. SB3 Work P; Texas Water Development Board: Austin, TX, USA, 2015.

129. Norton, S.B.; Cormier, S.M.; Suter, G.W.; Subramanian, B.; Lin, E.; Altfater, D.; Counts, B. Determining probable causes of ecological impairment in the Little Scioto River, Ohio, USA: Part 1. Listing candidate causes and analyzing evidence. Environ. Toxicol. Chem. 2002, 21, 1112-1124. [CrossRef]

130. Meyer, J.L.; Sale, M.J.; Mulholland, P.J.; Poff, N.L. Impacts of climate change on aquatic ecosystem functioning and health. JAWRA J. Am. Water Resour. Assoc. 1999, 35, 1373-1386. [CrossRef]

131. Thompson, J.; Laizé, C.; Green, A.; Acreman, M.; Kingston, D. Climate change uncertainty in environmental flows for the Mekong River. Hydrol. Sci. J. 2014, 59, 935-954. [CrossRef]

132. Wildsmith, M.D.; Rose, T.H.; Potter, I.C.; Warwick, R.M.; Clarke, K.R.; Valesini, F.J. Changes in the benthic macroinvertebrate fauna of a large microtidal estuary following extreme modifications aimed at reducing eutrophication. Mar. Pollut. Bull. 2009, 58, 1250-1262. [CrossRef] [PubMed]

133. Dyson, M.; Bergkamp, G.; Scanlon, J. (Eds.) Flow: The Essentials of Environmental Flows; IUCN The World Conservation Union: Gland, Switzerland, 2003; pp. 11-28.

134. Naiman, R.J.; Bunn, S.E.; McClain, M.E.; Vorosmarty, C.J.; Zalewski, M. The Science of Flow-Ecology Relationships: Clarifying Key Terms and Concepts. 2006. Available online: www.unesco.org/water/ihp/ecohydrology/pdf/ (accessed on 30 June 2020).

135. Davis, M.D. Integrated Water Resource Management and Water Sharing. J. Water Resour. Plan. Manag. 2007, 133, 427-445. [CrossRef]

136. Pegram, G.; Li, Y.; Le Quesne, T.; Speed, R.; Li, J.; Shen, F. River Basin Planning: Principles, Procedures and Approaches for Strategic Basin Planning; UNESCO: Paris, France, 2013. 